7-1-2013

\title{
A Reliance Approach to Precedent
}

Hillel Y. Levin

University of Georgia School of Law, hlevin@uga.edu

DSPRN

\section{Repository Citation}

Hillel Y. Levin, A Reliance Approach to Precedent , 47 Ga. L. Rev. 1035 (2013),

Available at: https://digitalcommons.law.uga.edu/fac_artchop/921

This Article is brought to you for free and open access by the Faculty Scholarship at Digital Commons @ University of Georgia School of Law. It has been accepted for inclusion in Scholarly Works by an authorized administrator of Digital Commons @ University of Georgia School of Law. Please share how you have benefited from this access For more information, please contact tstriepe@uga.edu. 


\title{
GEORGIA LAW REVIEW
}

NUMBER 4

\section{ARTICLES}

\section{A RELIANCE APPROACH TO PRECEDENT}

\author{
Hillel Y. Levin*
}

\section{TABLE OF CONTENTS}

I. INTRODUCTION

II.

PRECEDENT: STAKES AND TRADITIONAL

JUSTIFICATIONS

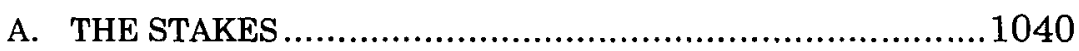

B. UNSATISFACTORY JUSTIFICATIONS FOR PRECEDENT ... 1044

1. Public Faith in the Judiciary ..............................1044

2. Judicial Efficiency ...........................................1047

3. Equality .......................................................... 1048

4. Super-Strong Precedent in the Statutory

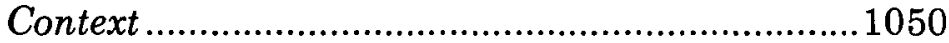

III. THE RELIANCE APPROACH TO PRECEDENT .......................1053

A. THE CORE FUNCTION OF LAW AND COURTS..................1054

B. RELATIVE JUDICIAL AND LEGISLATIVE

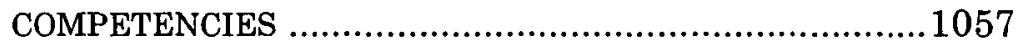

C. SCHOLARLY AND JUDICIAL PRECURSORS ...................1060

* Associate Professor of Law, University of Georgia School of Law; J.D., Yale University. The author thanks Larry Solum, Bill Eskridge, Randy Kozel, Max Minzner, Kay Levine, Michael Perry, Lori Ringhand, Harlan Cohen, Christian Turner, and Tim Meyer for their input and thoughts. He is especially grateful for the first-rate research assistance of Barclay Hendrix. 
IV. IMPLICATIONS: LIMITING AND EXPANDING PRECEDENT ... 1067

A. LIMITING PRECEDENT .............................................1068

1. Category 1: Cases That Cannot Generate Reliance Interests.................................................1068

2. Category 2: Cases That Could but Do Not Generate Reliance Interests .................................1071

3. Category 3: Cases in the Middle ...........................1072

B. EXPANDING PRECEDENT ...........................................1073

1. The Decisions of Sister and Lower Courts ............1074

2. Equitable Estoppel in Administrative Law..........1078

3. Public Discourse and Practice ..............................1082

a. In re Rachel L. .............................................1082

b. Sherley v. Sebelius........................................1083

c. United States v. Nosal....................................1086

V. OBJECTIONS AND REFINEMENTS ..................................1090

A. THE EVIL PRECEDENT PROBLEM ...............................1090

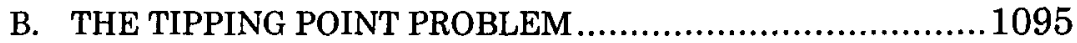

VI. CONCLUSION: REVISING THE GRAVITATIONAL ACCOUNT

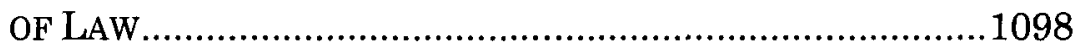




\section{INTRODUCTION}

Anyone trained in legal argument is familiar with the topic of precedent, surely one of the most fundamental concepts within American jurisprudence. ${ }^{1}$ It lies at the heart of our most pressing debates at the intersection of law and policy, including those concerning abortion, immigration, health-care law, and same-sex marriage. Reams of paper have been devoted to the subject, ${ }^{2}$ and judges and commentators have developed and debated a sophisticated taxonomy that includes such terms as binding precedent, ${ }^{3}$ persuasive precedent, ${ }^{4}$ dicta,${ }^{5}$ foreign precedent, ${ }^{6}$ stare decisis, ${ }^{7}$ super precedent, ${ }^{8}$ and super-strong statutory precedent. ${ }^{9}$

1 See Christopher J. Peters, Foolish Consistency: On Equality, Integrity, and Justice in Stare Decisis, 105 YALE L.J. 2031, 2037 (1996) ("[Stare decisis] is the most important application of a theory of decisionmaking consistency in our legal culture ...."); see also Thomas Healy, Stare Decisis and the Constitution: Four Questions and Answers, 83 NOTRE DAME L. REV. 1173, 1174 (2008) ("[S]tare decisis has emerged as one of the most contested and interesting topics in constitutional law."); Gary Lawson, The Constitutional Case Against Precedent, 17 HARV. J.L. \& PUB. POL'Y 23, 23 (1994) ("Legal analysis-by lawyers, courts, and academics-typically begins and ends with precedent."); Frederick Schauer, Precedent, 39 STAN. L. REV. 571, 571 (1987) ("An appeal to precedent is a form of argument ... that is often as persuasive as it is pervasive.").

2 See David L. Shapiro, The Role of Precedent in Constitutional Adjudication: An Introspection, 86 TEX. L. REV. 929, 929 (2008) ("In recent years, there has been a surprising outpouring of academic literature on the proper role of precedent....").

${ }^{3}$ E.g., Henry Paul Monaghan, Stare Decisis and Constitutional Adjudication, 88 CoLUM. L. REV. 723, 756-57 (1988).

${ }_{4}$ E.g., Erica S. Weisgerber, Note, Unpublished Opinions: A Convenient Means to an Unconstitutional End, 97 GEO. L.J. 621, 633-34 n.55 (2009); see generally Chad Flanders, Toward a Theory of Persuasive Authority, 62 OKLA. L. REV. 55 (2009).

5 E.g., Michael Abramowicz \& Maxwell Stearns, Defining Dicta, 57 STAN. L. REv. 953, 955 (2005).

6 E.g., Pradyumna K. Tripathi, Foreign Precedents and Constitutional Law, 57 ColuM. L. REv. 319, 321 (1957); John Yoo, Peeking Abroad?: The Supreme Court's Use of Foreign Precedents in Constitutional Cases, 26 U. HAW. L. REv. 385, 385-87 (2004).

7 See, e.g., Monaghan, supra note 3, at 723 (discussing conflict between stare decisis and originalism); see generally Trevor W. Morrison, Stare Decisis in the Office of Legal Counsel, 110 COLUM. L. REV. 1448 (2010). The terms "precedent" and "stare decisis" are often used interchangeably. Weisgerber, supra note 4, at 633 n.55.

8 E.g., Michael J. Gerhardt, Super Precedent, 90 MiNN. L. REV. 1204, 1205 (2006).

9 See William N. Eskridge, Jr., Overruling Statutory Precedents, 76 GEo. L.J. 1361, 1362 (1988) ("Statutory precedents . . . often enjoy a super-strong presumption of correctness."). 
Still, the most basic questions about precedent remain: Why should a court defer to its earlier decisions?10 And when, if ever, should precedent give way? The absence of satisfying answers to these questions has bred confusion among both judges and scholars. ${ }^{11}$

This Article argues that the central justification for adhering to even erroneous precedent-and also for precedent's centrality within our legal order-is what I call the reliance approach. ${ }^{12}$ Under this approach, precedent matters because, and therefore when, the public has developed reliance interests on the basis of earlier judicial opinions. Rule-of-law principles and the relative institutional competencies of the courts and legislatures require that judges should usually not interfere with these interests by overturning even wrongly decided precedents. I should be clear at the outset that the focus of this Article is on what scholars have called "horizontal precedent," that is, previous rulings issued by the same court. ${ }^{13}$

10 As Fred Schauer has put the question, "[w]hy should the best decision for now be distorted or thwarted by obeisance to a dead past?" Schauer, supra note 1, at 571.

${ }_{11}$ See, e.g., Daniel A. Farber, The Rule of Law and the Law of Precedents, 90 MINN. L. REV. 1173, 1173-74 (2006) (describing the "relationship between precedent and the rule of law" as "hotly contested" and reviewing competing theories and differing applications of precedent in several cases). Farber goes on to usefully contrast the views of Justice Powell, a minimalist who stressed the importance of precedent for the sake of stability and maintenance of respect for the judiciary, with those of Justice Scalia, who stresses fidelity to the law over fidelity to the Court. Id.

${ }_{12}$ Strictly speaking, it is not necessary that the doctrine of precedent have only one justification. However, as I demonstrate infra, the primary alternative justifications offered for precedent do not account for its centrality within our legal order or its operation in practice. This is not to say that these alternatives should never be considered by judges, only that much more is needed. The central insight of this Article is that the reliance approach offers the primary, overarching explanation for the doctrine of precedent that best describes its moral force, captures many of its features, and provides guidance for how judges should address the precedent question.

${ }_{13}$ See, e.g., Randy J. Kozel, Precedent and Reliance, 62 EMORY L.J. (forthcoming 2013) (manuscript at 11) (on file with author) (distinguishing between horizontal and vertical precedent). The question of why lower courts must adhere to the rulings of higher courts"vertical precedent"-is beyond the scope of this Article. See Shapiro, supra note 2, at 929 ("'V]ertical' stare decisis [refers to] the question whether and to what extent higher court precedents should bind lower courts ...."); see generally Evan H. Caminker, Why Must Inferior Courts Obey Superior Court Precedents?, 46 STAN. L. REv. 817 (1994) (discussing "hierarchical" precedent). 
Although some judges and legal scholars have identified reliance as a relevant factor for the doctrine of precedent, their treatment of the issue has been cursory. ${ }^{14}$ They do not describe what they mean by reliance, explain why it has jurisprudential force, or explore how it differs practically from the alternative approaches to precedent. Instead, they simply add the word "reliance" to a litany of reasons why precedent should matter. Consequently, the reliance approach has been undertheorized in the scholarly literature and applied inconsistently by courts.

This Article fills this lacuna by exploring the reliance approach to precedent in depth. In doing so, I make the case that reliance should be the primary factor in deciding whether and when to adhere to precedent. Importantly, the reliance approach at once limits and expands our notion of what should "count" as precedent. First, under this approach, precedent should carry force only when the public's reliance interests would be substantially undermined were the court to reject the precedent. In the many cases in which reliance interests are low or nonexistent, judges may discount precedent. Simultaneously, though, this approach expands the universe of precedent. After all, there are other sources and phenomena that trigger reliance. For example, the decisions of sister and lower courts may set public behaviors. Further, even nonjudicial sources such as agency declarations and social behavior may give rise to legitimate reliance interests in some cases. If such interests are sufficient to require application of precedent when the precedential case was issued by the same court, then they should apply in these cases as well.

This Article proceeds as follows. Part II reviews the central role that precedent plays in current legal debates and critically examines traditional justifications for adherence to precedent. Part III then introduces the reliance approach as the most important organizing principle for the doctrine of precedent and

14 As Randy Kozel explains in a forthcoming article that considers other aspects of the intersection between reliance and precedent, "[f]or all its insights, the existing literature on stare decisis has relatively little to say about the doctrine's function as a mechanism to protect precedential reliance." Kozel, supra note 13 (manuscript at 9). 
explores its jurisprudential foundations and precursors in the scholarly and judicial literature. Next, Part IV examines the implications of the reliance approach by exploring the ways in which it both limits and expands the kinds of sources that may qualify as precedent. It also considers how the reliance approach may be applied in several actual cases. In doing so, Part IV demonstrates that some aspects of the reliance approach are implicitly, though only embryonically, manifested in legal discourse.

Part $\mathrm{V}$ then considers possible objections to and problems with the reliance approach. Grappling with such objections and problems helps us to refine the approach and, simultaneously, to understand both the reluctance of judges and scholars to fully embrace it and the persistence of a formal approach to precedent. The Article concludes by suggesting that the reliance approach demands a revision of conventional wisdom of the nature of legal doctrine and challenges judges and legal scholars to adopt what I call a bi-gravitational approach to the law that considers lower courts, administrative agencies, and public behaviors as sources of law.

\section{PRECEDENT: STAKES AND TRADITIONAL JUSTIFICATIONS}

I begin by briefly reviewing the central role that precedent plays in judicial and public discourse. ${ }^{15} \mathrm{I}$ then critically examine several of the most common justifications for adherence to precedent. I argue that these justifications are ultimately unsatisfactory because they do not account for judicial practice or the centrality of the doctrine within legal discourse.

\section{A. THE STAKES}

Virtually every brief filed before every court cites to and reasons from precedent. ${ }^{16}$ So does every reasoned judicial opinion. ${ }^{17}$ And

\footnotetext{
15 The discussion is brief because, in truth, few law-trained readers require much convincing for the proposition that precedent is important.

16 Lawson, supra note 1 , at 23.

17 Id. As previously noted, some uses of precedent are beyond the scope of this Article.
} 
scholarly, political, and public debates on important legal questions routinely invoke precedent. This hyper-focus on precedent reveals a critical point about our legal order: courts, lawyers, and scholars do not cite to earlier cases merely to forecast what the Supreme Court will do. Rather, they cite to precedent to argue what the courts should do. Their argument is that because a court has done $X$ in a previous case, it should do $X$ (or something similar to it) in a new case. In other words, the existence of a precedent is a reason in itself for a court to hold one way or another. ${ }^{18}$

Consider, for example, the question whether there is a constitutional right of access to abortion. When the Supreme Court confronts a case concerning abortion, the briefs are littered with references to the leading cases of $R o e^{19}$ and Casey, ${ }^{20}$ as well as to other cases more closely on point. For example, in Stenberg $v$. Carhart, ${ }^{21}$ the parties vigorously debated the application of Roe and Casey to Nebraska's so-called partial-birth abortion ban. ${ }^{22}$ Subsequently, in Gonzales v. Carhart, ${ }^{23}$ relating to a similar federal ban, the parties argued about the proper application of Roe, Casey, and Stenberg. ${ }^{24}$ Similarly, when public and political

These uses involve citations to vertical precedent, which requires a different analysis. See supra note 13 . In most cases, though, citations and arguments appeal to horizontal precedent. See Lawson, supra note 1, at 23 ("Court [o]pinions . . frequently consist entirely of discussions of past decisions ....").

18 Schauer, supra note 1 , at 575 (noting an "argument from precedent ... urges that a decisionmaker give weight to a particular [past decision] regardless of whether that decisionmaker believes it to be correct").

19 Roe v. Wade, 410 U.S. 113 (1973).

20 Planned Parenthood of Se. Pa. v. Casey, 505 U.S. 833 (1992).

21530 U.S. 914 (2000).

22 Petitioners argued that both Roe and Casey made clear that the right to abortion is "not absolute." and women are not entitled to terminate their pregnancies in whatever way they choose, such that the ban on partial-birth abortion should be upheld. Brief of Petitioners at 8 , Stenberg v. Carhart, 530 U.S. 914 (2000) (No. 99-830), 2000 WL 228613, at *8. Respondents, meanwhile, argued that the ban "eviscerate[d] the key protections guaranteed to American women by Roe and Casey." Brief of Respondent at 18, Stenberg, 530 U.S. 914 (No. 99-830), $2000 \mathrm{WL} 340275$, at ${ }^{\star} 18$.

23550 U.S. 124 (2007).

24 Petitioners argued their case was distinguishable from Stenberg, and the ban should be upheld under the "undue burden" standard for assessing its constitutionality under Roe and Casey. Brief for the Petitioner at 12-13, Gonzales, 550 U.S. 124 (No. 05-380), 2006 WL 
discourse turns to abortion, the question of the precedential value of Roe and Casey often plays a primary role; ${ }^{25}$ rarely does a senator ask a Supreme Court nominee for his or her opinion about when life begins. Rather, the questioning focuses on the nominee's commitment to precedent with respect to Roe. ${ }^{26}$

The same pattern is apparent in the debates over the constitutionality of the "Obamacare" individual mandate under the Commerce Clause. Both sides extensively debated whether and how previous decisions about the regulatory state applied to the individual mandate. ${ }^{27}$ Is a requirement to purchase health insurance merely one among many laws that punish inactivity by individuals, ${ }^{28}$ or is it unique?29 Does it affect interstate commerce the same way as a ban on growing marijuana for personal use, ${ }^{30}$ or

1436690 , at *12-13. Respondents argued striking down the ban would be consistent with Stenberg and that case's reading of Roe and Casey. Brief of Respondents at 18-19, Gonzales, 550 U.S. 124 (No. 05-380), 2006 WL 2345934, at *18-19.

${ }^{25}$ Amy Goldstein \& Charles Babington, Roberts Avoids Specifics on Abortion Issue, WASH. POST, Sept. 14, 2005, at A01; see also Emotions Run High in Alito Hearing's 3rd Day, MSNBC.COM, Jan. 11, 2006, http://www.msnbc.msn.com/id/10802815/ns/us_news-the_chan ging_court/t/emotions-run-high-alito-hearings-3rd-day/.

${ }_{26}$ See Gerhardt, supra note 8, at 1204 (discussing the questioning of John Roberts during his confirmation hearings).

${ }^{27}$ Those in favor of the individual mandate argued it was a valid exercise of Congress's commerce power, citing cases such as United States v. Lopez, 514 U.S. 549 (1995), for the proposition that Congress may regulate activity that substantially affects interstate commerce and arguing that people failing to purchase health insurance distorts interstate markets for health care. Petition for a Writ of Certiorari at 15, U.S. Dep't of Health \& Human Servs. v. Florida, 132 S. Ct. 2566 (2012) (No. 11-398). Those against the mandate argued that requiring citizens to buy health insurance was a "wholly novel and potentially unbounded assertion of congressional authority." Brief for State Respondents at 9, U.S. Dep't of Health \& Human Servs., 132 S. Ct. 2566 (No. 11-398).

${ }_{28}$ See Petition for a Writ of Certiorari, supra note 27, at 20 (arguing that it has long been settled that Congress can act preemptively and "need not 'await the disruption of . . . commerce' " to exercise its commerce powers).

29 See Brief for State Respondents, supra note 27, at 9 (describing it as "wholly novel").

30 See Petition for a Writ of Certiorari, supra note 27, at 21 (analogizing people who do not purchase insurance to home growers of marijuana for medical use and arguing that, in the same way Congress can regulate the growers because their marijuana is "never more than an instant from the interstate market," so too may Congress regulate people who fail to buy insurance because all people are "'never more than instant' from the "'point of consumption' of health care" (quoting Gonzales v. Raich, 541 U.S. 1, 40 (2005) (Scalia, J., concurring in the judgment))). 
is it vastly different? ${ }^{31}$ In other words, is it unprecedented, or is it, well, precedented? ${ }^{32}$

The list goes on. In debating whether federal law preempts Arizona's immigration laws, ${ }^{33}$ the parties and the courts contested the applicability of leading preemption cases such as Hines $v$. Davidowitz ${ }^{34}$ and Pennsylvania $v$. Nelson. ${ }^{35}$ In the fight over whether the Constitution requires recognition of same-sex marriage, opponents and proponents fixate on Lawrence $v$. Texas, ${ }^{36}$

${ }^{31}$ See Ilya Somin, A Mandate for Mandates: Is the Individual Health Insurance Case a Slippery Slope?, 75 LAW \& CONTEMP. PROBS. 75, 80 (2012) (arguing that "Raich does not determine the outcome of the mandate case" because "[p]eople without health insurance are not-by virtue of that status-producing, consuming, or distributing a commodity of any kind," and thus they do not fit the definition of economic activity relied on by Raich).

32 Compare Randy Barnett, Judicial Minimalism and the Individual Mandate, THE VOLOKH CONSPIRACY (May 20, 2012, 5:05 PM), http://www.volokh.com/2012/05/20/judicialminimalism-and-the-individual-mandate/ ("If the Supreme Court invalidates the individual insurance mandate, it need not call into question any other law that has ever been passed in the history of the United States."), with Petition for a Writ of Certiorari, supra note 27, at 15-21 (arguing that the mandate was fully in line with established Commerce Clause precedent).

33 Arizona v. United States, 132 S. Ct. 2492 (2012).

34312 U.S. 52 (1941).

35350 U.S. 497 (1956). Arizona argued that its laws were not preempted, relying on a line of cases that says Congress must have clearly intended to preempt state law before a court can find that it did so. See Brief for Petitioners at 27-28, Arizona, 132 S. Ct. 2492 (No. 11-182), 2012 WL 416748, at *27-28 ("[C]ourts may not find state measures preempted in the absence of clear evidence that Congress so intended." (quoting California v. FERC, 495 U.S. 490, 497 (1990))); see also Wyeth v. Levine, 555 U.S. 555, 565 (2009) (" $[\mathrm{I}] \mathrm{n}$ all pre-emption cases ... we 'start with the assumption that the historic police powers of the States were not to be superseded by the Federal Act unless that was the clear and manifest purpose of Congress.' " (internal quotation marks omitted)). The United States relied on a different line of preemption cases to argue that Arizona's attempt to punish violations of federal law intruded on exclusive federal authority because alien registration is a field preempted by Congress. See Brief for the United States at 26-27, Arizona, 132 S. Ct. 2492 (No. 11-182), 2012 WL 939048, at *26-27 (citing Hines, 312 U.S. at 66 (striking down a state alien-registration statute because federal law created a "complete scheme of registration" that occupied the field) and Nelson, 250 U.S. at $504 \mathrm{n} .21$ ("[A]lien registration" is a field of "dominant federal interest" where "Congress manifestly did not desire concurrent state action.")).

${ }^{36} 559$ U.S. 538 (2003). Compare Defendant-Intervenors-Appellants' Opening Brief at 112, Perry v. Schwarzenegger, 671 F.3d 1052 (9th Cir. 2012) (No. 10-16696), 2010 WL 3762119 , at *112 [hereinafter Appellants' Opening Brief] (arguing that Lawrence does not require the ban on homosexual marriage to be struck down because "Lawrence specifically said that the case 'did not involve whether the government must give formal recognition to any relationship that homosexual persons seek to enter.' " (quoting Lawrence, 559 U.S. at 
Romer v. Evans, ${ }^{37}$ Loving v. Virginia, ${ }^{38}$ and even Baker v. Nelson, in which the Court summarily rejected a claim by a same-sex couple for marital recognition. ${ }^{39}$

We would find the same pattern in every case before the Supreme Court. But why should decisions of the past hold such sway over the present and future?

\section{B. UNSATISFACTORY JUSTIFICATIONS FOR PRECEDENT}

The topic of precedent has received substantial attention in the scholarly and judicial literature. ${ }^{40}$ Indeed, "[d]ebates about the role of precedent are as old as precedent itself." 41 Here, I briefly review that literature and show that several conventional theories of precedent offer unpersuasive justifications, inaccurately describe judicial practice, or fail to account for why precedent features so centrally within our legal order.

1. Public Faith in the Judiciary. One justification offered for the doctrine of precedent is that it promotes public faith in the judiciary, ${ }^{42}$ for if judges routinely changed their minds, the public

578)), with Brief for Appellees at 36, Perry, 671 F.3d 1052, 2010 WL 4310749, at *36 (arguing that Lawrence applies to California's ban on gay marriage).

${ }^{37} 517$ U.S. 620 (1996). Compare Appellants' Opening Brief, supra note 36, at 104 (distinguishing Romer), with Brief for Appellees, supra note 36, at 36-37 (arguing that Romer applies to California's ban on same-sex marriage).

38388 U.S. 1 (1967); see Appellants' Opening Brief, supra note 36, at 51 ('[I]f there had been any merit at all in the claim that the fundamental right to marry includes the right to marry a person of the same sex, then surely the Court would not have dismissed, [Baker $v$. Nelson, just five years after Loving,] unanimously, the appeal for want of a substantial federal question.").

${ }^{39}$ Baker v. Nelson, 191 N.W.2d 185 (Minn. 1971), appeal dismissed, 409 U.S. 810 (1972). Compare Appellants' Opening Brief, supra note 36, at 44-45 (arguing Baker mandates dismissal because "[p]laintiffs assert the same claims as those rejected in Baker"), with Brief for Appellees, supra note 36, at 35 (arguing Baker is inapplicable because "summary dismissals are binding on lower courts only 'on the precise issues presented and necessarily decided' by the Court... and only to the extent they have not been undermined by subsequent 'doctrinal developments' in the Supreme Court's jurisprudence" (citations omitted)).

${ }^{40}$ See supra notes 1-11; see also Lewis F. Powell, Jr., Lecture, Stare Decisis and Judicial Restraint, 47 WASH. \& LEE L. REV. 281 (1990).

41 Healy, supra note 1, at 1177.

42 Martin Shapiro, Toward a Theory of Stare Decisis, 1 J. LEGAL STUD. 125, 133 (1972) (arguing stare decisis "provides supportive reassurance to each of the communicator 
would begin to doubt their wisdom, authoritativeness, and neutrality. Legal pronouncements would cease to be seen as infallible or "right" and instead would seem arbitrary or provisional. Worse, judges might come to be viewed merely as politicians in robes. ${ }^{43}$ As a consequence, the judiciary's accepted role as the final arbiter of "what the law is" 44 would erode. By deferring to precedent, judges preserve the authority of the judicial institution, ${ }^{45}$ a goal that is more important (in this telling) than that of correctly resolving the specific legal issue before the court. As Schauer suggests, courts are able to enhance their credibility and "increase the[ir] power" by adhering to precedent. ${ }^{46}$

The strongest proponent of this view among Supreme Court Justices has perhaps been Justice Powell, who argued that "elimination of constitutional stare decisis would represent an explicit endorsement of the idea that the Constitution is nothing more than what five Justices say it is." 47 It also features heavily in the plurality opinion in Casey, which reaffirmed the essential holding of Roe-a constitutional right of access to abortion. As the plurality suggested, "[t]he need for principled action to be perceived as such is implicated to some degree whenever this, or any other appellate court, overrules a prior case." 48 It went on to conclude that overruling Roe would inflict a blow to the Court's legitimacy and would contribute to the erosion of its authority ${ }^{49}$

The trouble with this account is twofold. First, it assumes without proving that the public has more faith in an institution that refuses to revisit the mistakes of the past than in one that tries to correct them. This is a questionable empirical assumption. As Justice Scalia has argued, "[w]e provide far greater reassurance

decision-makers that his fellows are with his fellows are with him"); Schauer, supra note 1, at 600 .

43 Powell, supra note 40, at 288.

44 Marbury v. Madison, 5 U.S. (1 Cranch) 137, 177 (1803).

45 See Powell, supra note 40, at 289-90 (" $[\mathrm{R}]$ estraint in decisionmaking and respect for decisions once made are the keys to preservation of an independent judiciary and public respect for the judiciary's role as a guardian of rights.").

46 Schauer, supra note 1 , at 600.

47 Powell, supra note 40, at 288.

48 Planned Parenthood of Se. Pa. v. Casey, 505 U.S. 833, 866 (1992).

49 Id. at 867. 
of the rule of law by eliminating than by retaining [an erroneous past] decision."50 Indeed, among those opposed to Roe, continued adherence to its core holding on the basis of stare decisis surely does little to fortify their faith in the Court. Likewise, had the Court in Lawrence v. Texas simply reaffirmed Bowers v. Hardwick on the ground that it was settled precedent, faith in the Court would likely not have risen among those who thought Bowers was wrongly decided. To put a fine point on it, whom would you likely trust more, the individual who admits to past mistakes or the one who insists that there have been none? If we justify precedent because it enhances public faith, then we ought to have some real evidence for the proposition. Yet we have none.

Second, the public-faith account demands a measure of deceit on the part of judges. Even the most doctrinaire formalists would concede that at least some judicial decisions are driven by judges' ideologies, values, and preferences, or at least that the Court sometimes gets things wrong. To adopt a judicial doctrine for the primary purpose of maintaining a public facade of neutrality and authoritativeness at the expense of righting such wrongs would be to con the public. ${ }^{51}$ The best way to encourage and maintain public faith in the judiciary is not to trick the public but to demonstrate honesty and fidelity to the law through careful deliberation and argumentation.

50 South Carolina v. Gathers, 490 U.S. 805, 825 (1989) (Scalia, J., dissenting).

51 A case can be made that judges do and must engage in some behaviors to maintain public faith in their honesty and fidelity to the law. To be clear, I am not taking a stand here on this question. I simply acknowledge that (1) there is value in promoting public faith in the judiciary, (2) this value may sometimes be in tension with the value of honesty, and (3) a reasonable argument may be made in some circumstances that the need for faithpromotion may trump the value of complete candor. But we ought to at least limit such practices to procedural mechanisms. For example, judges may wear robes and adopt other symbols and trappings for the purpose of appearing authoritative and neutral. Judith Resnik, Managerial Judges, 96 HARV. L. REV. 374, 383 (1982). Likewise, recusal rules and practices are meant to reinforce public faith in the judiciary. Indeed, even some core judicial practices like engaging in oral argument may serve primarily as a public display of deliberation in those cases in which judges have already made up their minds. But such procedural practices help to promote public faith at little cost to the integrity of the law's substance. In contrast, if the substantive doctrine of precedent were to be justified primarily on the basis of promoting public faith and enhancing the power of the courts, it would be at the expense of better substantive law. That price is too high. 
2. Judicial Efficiency. A second explanation for the value of precedent is that it serves the interests of judicial efficiency. In this telling, judges simply do not have the time or resources to carefully reconsider each and every previous decision. ${ }^{52}$ "It is simply unworkable to leave everything up for grabs all of the time," 53 and the doctrine of precedent allows judges to conserve judicial resources rather than to constantly reinvent the wheel.

Although this justification may explain why courts elect not to rehash and re-reason each and every case from first principles, it does little to explain why judges who are convinced that an earlier decision may have been wrong should not reconsider it. Thus, it provides a descriptive explanation for deference to precedent, but not the normative justification that the doctrine demands. Of course, if judges always deferred to precedent, they would achieve a substantial gain in efficiency. But this does not accurately describe the practice of deferring to precedent in the courts. The Supreme Court has never categorically refused to reconsider precedent. Everyone agrees that some precedents may be overturned. ${ }^{54}$ But a judge cannot reasonably say, "I am overturning precedent in case $A$ because the earlier decision was wrong, but not in case $B$ because doing so is a waste of judicial resources."

Second, given that the bulk of the analysis in a judicial opinion often focuses on analogizing to and distinguishing from precedent, it is not altogether clear that the doctrine of precedent actually conserves judicial resources. Instead, it may simply shift judges' work away from reasoning from first principles and toward reasoning their way through a tangled web of related cases.

If we focus on the Supreme Court, the efficiency justification is weaker still. In contrast to the federal intermediate appellate

\footnotetext{
52 Jonathan R. Macey, The Internal and External Costs and Benefits of Stare Decisis, 65 CHI.-KENT L. REV. 93, 102 (1989); Schauer, supra note 1, at 599.

53 Farber, supra note 11, at 1177; see also BENJAMIN N. CARDOzo, THE NATURE OF THE JudICIAL PROCESS 149 (1921) ("[T]he labor of judges would be increased almost to the breaking point if every past decision could be reopened in every case . . ..").

${ }_{54}$ See Smith v. Allwright, 321 U.S. 649, 665 (1944) ("[W]hen convinced of former error, this Court has never felt constrained to follow precedent.").
} 
courts, which consider tens of thousands of cases each year, ${ }^{55}$ the Supreme Court chooses its own docket and, in the recent past, has elected to shrink its caseload to roughly seventy-five cases a year. ${ }^{56}$ The argument that the Justices' resources are spread too thin to allow them to consider overturning precedent in at least these cases rings somewhat hollow. One suspects that they could even hear a few more cases implicating questionable precedents or, at the very least, take the necessary time to consider the continued viability and desirability of earlier decisions in the cases they have chosen to hear.

Perhaps most importantly, even if the efficiency explanation does have normative force, it is underwhelming as a justification for precedent's central role in our legal order. The efficiency justification proposes that the doctrine of precedent exists because judges do not have the time or resources to do without it. As such, precedent is something of a second-best option-a necessary but not fundamentally desirable feature of our system. If this is true, then it is a case of the tail wagging the dog, given the doctrine's prominence in judicial rhetoric and legal discourse.

3. Equality. A third possible justification for adhering to precedent emerges from the maxim that "like cases should be treated alike." 57 Under this rationale, the courts would violate a basic rule-of-law principle if, for example, they were to decide on one day that a person may be executed for committing a particular crime and then on the next that someone else may not be executed for committing the same crime. By adhering to precedent, courts thus help ensure equality. ${ }^{58}$ Whereas the first two rationales for precedent were concerned primarily with the internal functioning

55 U.S. Courts of Appeals (Circuit Courts), THE LEADERSHIP CONFERENCE, http://www.civ ilrights.org/judiciary/courts/appeals.html (last visited Apr. 8, 2013).

${ }_{56}$ Frequently Asked Questions, SUPREME COURT OF THE U.S., http://www.supremecourt. gov/faq.aspx\#faqgi9 (last visited Apr. 8, 2013).

57 E.g., Schauer, supra note 1, at 595-96.

58 The moral or ethical core of this argument traces back at least as far as Aristotle: "Equality in morals means this: things that are alike should be treated alike, while things that are unalike should be treated unalike in proportion to their unalikeness." ARISTOTLE, ETHICA Nicomachea, in THE WORKS OF ARISTOTLE V.3.1131a-1131b (W.D. Ross ed. \& trans., 1954) (c. 384 B.C.E.). 
and public perception of the courts, the equality justification is attractive because it offers a strong moral foundation for the doctrine, suggesting that adhering to precedent produces more just laws. Unfortunately, the equality justification is also not entirely persuasive.

First, there is something unsettling about claiming that a court must affirm what it believes to be a poor past decision in order to uphold equality. Consider again the case of the death penalty. In case $A$, a court held that a particular crime may subject someone to the death penalty, and that person was subsequently executed. Later, in case $B$, the judges are convinced that the Constitution prohibits execution for the very same crime. Executing the defendant in case $B$ simply on the grounds of equality defies sense. If the equality rationale is to offer any basis for adherence to precedent, then, it must be refined and cabined. At most, equality demands that like cases be treated alike unless there is a nonarbitrary reason to treat them differently. This principle explains why we should not flip a coin to determine the punishment for a crime. In contrast, the judges' belief that a previous decision of the court was incorrect is not arbitrary, and equality therefore does not demand that courts adhere to precedent. Alternatively, we may view a judge who declines to uphold precedent as treating cases $A$ and $B$ fully alike in that the judge in both cases does the very best to give the Constitution its best interpretation and application..$^{59}$

Second, the equality justification is suspect because it does not describe reality. Many features of our justice system guarantee that like cases are often treated unalike, sometimes even for arbitrary reasons: prosecutorial discretion, ${ }^{60}$ economic factors that

59 There is a rich literature on the problems with the "treat like cases alike" approach to precedent and law more generally. E.g., Schauer, supra note 1, at 595-97; Peter Westen, The Empty Idea of Equality, 95 HARV. L. REV. 537 (1982); Kenneth I. Winston, On Treating Like Cases Alike, 62 CAL. L. REV. 1 (1974).

60 The doctrine of prosecutorial discretion gives prosecutors substantial leeway in deciding when and how to charge a defendant, as well as whether to offer plea agreements. Wayte v. United States, 470 U.S. 598, 607 (1985); United States v. Batchelder, 442 U.S. 114,124 (1979). As a practical matter, this means that two people who commit the same crime may be treated differently by prosecutors. 
allow some to afford excellent lawyers and others to afford poor lawyers, ${ }^{61}$ differences between juries, ${ }^{62}$ different practices among judges, ${ }^{63}$ and so on. If the equality argument is taken seriously, why does it not apply in these areas?

Finally, if equality concerns animated the doctrine of precedent, then this principle would also substantially constrain a legislature's ability to change the law. That is, the equality argument offers no reason for treating courts and legislatures differently; if it is wrong for courts to change the law such that it would apply unequally in similar cases, then it is also wrong for the legislature to do so. Yet no one argues that legislatures must adhere to their own precedents, and there would surely be no equality-based objection to the legislature abolishing the death penalty simply because previous legislatures established it. Any normative justification for the doctrine of precedent must offer a basis for distinguishing between courts and legislatures, but the equality argument appears to offer none.

4. Super-Strong Precedent in the Statutory Context. Traditionally, courts have given even greater deference to precedents concerning questions of statutory interpretation and application than they have to constitutional and common law precedents. ${ }^{64}$ The justification for this "super-strong" statutory precedent rule $^{65}$ is that legislative silence suggests acquiescence to a court's interpretation of a statute, or even that the legislature agrees that the court's interpretation of the statute was correct. ${ }^{66}$ As Guido Calabresi put it, "[w]hen a court says to a legislature:

61 See generally AM. BAR AsSOC., GIDEON'S BROKEN PROMISE: AMERICA's ConTINUING QUEST FOR EQUAL JUSTICE (2004), available at http://www.americanbar.org/groups/legal_a id_indigent_defense_systems_imprisonment/gideons_broken_promise.html.

62 See McClesky v. Kemp, 481 U.S. 279, 311-12 (1987) ("[T] predictability of jury decisions does not justify their condemnation.... Apparent disparities in sentencing are an inevitable part of our criminal justice system.").

63 See generally U.S. Gov'T ACCOUNTABILITY OFFICE, GAO-08-940 U.S. ASYLUM SYSTEM: SigNIFICANT VARIATION EXISTED IN ASYLUM OUTCOMES ACROSS IMMIGRATION COURTS AND JUDGES (2008), available at http://www.gao.gov/assets/290/281794.pdf.

64 Eskridge, supra note 9 , at 1365.

65 The term comes from Eskridge. Id. at 1366.

${ }^{66} I d$. at 1366-67; see also GUIDO CALABRESI, A COMMON LAW FOR THE AGE OF STATUTES 31-32 (1982). 
'You (or your predecessor) meant X,' it almost invites the legislature to answer: 'We did not." "67

This justification, too, has limitations. Most obviously, it only explains why judges should defer to precedent in the statutory context; it has nothing at all to say about precedent's value in nonstatutory cases. This is not a critique of the justification, which after all has no broader ambitions. But precedent is a much more expansive jurisprudential principle, not confined to the statutory context. Indeed, the judicial and scholarly literature on precedent typically focuses on the constitutional context. ${ }^{68}$ Thus, even if we were to accept the legislative-acquiescence justification for precedent, we would not succeed in explaining the importance of precedent as a foundational principle in the law.

We must also narrow the potential applicability of this justification even further, for it can only reasonably apply to statutory precedents from the Supreme Court. Congress typically is oblivious to lower-court opinions, which receive little media attention, and thus has no real opportunity to override such opinions legislatively, ${ }^{69}$ and it rarely responds to opinions issued by the federal appellate courts. ${ }^{70}$ Therefore, with respect to such decisions, the legislative-acquiescence argument carries little force.

There are also good reasons to be skeptical that the possibility of legislative override provides a reasonable justification even when appropriately limited. Although Congress sometimes does respond to statutory decisions issued by the Supreme Court, there

67 CALABRESI, supra note 66, at 31-32. For related reasons, it has also been suggested that the availability of congressional override in the statutory context mitigates countermajoritarian concerns. E.g., Lawrence C. Marshall, "Let Congress Do It": The Case for an Absolute Rule of Statutory Stare Decisis, 88 MICH. L. REV. 177, 204 (1989); Deborah A. Widiss, Shadow Precedents and the Separation of Powers: Statutory Interpretation of Congressional Overrides, 84 NOTRE DAME L. REV. 511, 519-21 (2009).

68 See generally Randy E. Barnett, Response, It's a Bird, It's a Plane, No, It's Super Precedent: A Response to Farber and Gerhardt, 90 MINN. L. REV. 1232 (2006); Schauer, supra note 1.

69 Amy Coney Barrett, Statutory Stare Decisis in the Courts of Appeals, 73 GEO. WASH. L. REV. 317, 331 (2005)

70 Stefanie A. Lindquist \& David A. Yalof, Congressional Responses to Federal Circuit Court Decisions, 85 JuDICATURE, no. 2, Sept.-Oct. 2001, at 61. 
are many reasons that it may not do so even if a particular opinion was incorrect. ${ }^{71}$ Given the series of "vetogates" that a bill must pass through to become law, it is implausible to expect Congress to consistently override incorrect judicial opinions. ${ }^{72}$ Similarly, legislative priorities and political factors may be such that Congress cannot fix the Court's errors. ${ }^{73}$ Indeed, the legislators who enacted the initial statute that was wrongly interpreted may have been replaced with legislators for whom the issue in question ranks low in priority or who prefer the policy produced by the Court's decision, even if the decision was a poor interpretation of the statute in question. ${ }^{74}$ Given that legislative inaction does not provide strong evidence of the meaning of the statute or the current legislature's preferences, it is a dubious business to adhere to precedent simply because congressional override is theoretically available..$^{75}$ It is perhaps for these reasons that the super-strong statutory precedent rule has eroded in recent years. ${ }^{76}$

71 See Johnson v. Transp. Agency, 480 U.S. 616, 671 (1987) (Scalia, J., dissenting) (arguing that the assumption the Court's decision is correct because Congress fails to pass legislation rejecting it is based on false premises); ANTONIN SCALIA, A MATTER OF INTERPRETATION: FEDERAL COURTS AND THE LAW (1997); Eskridge, supra note 9, at 1409 (arguing that the super-strong presumption against overruling statutory precedent should be abandoned).

72 William N. Eskridge, Jr., Vetogates, Chevron, Preemption, 85 Notre Dame L. Rev. $1441,1444-48$ (2008).

${ }^{73}$ Johnson, 480 U.S. at 671-72 (Scalia, J., dissenting) ("[O]ne must ignore rudimentary principles of political science to draw any conclusions regarding [the current Congress's] intent from the failure to enact legislation."); Eskridge, supra note 9, at 1405 ("The vagaries of the political process make it hard to determine what Congress' 'positive inaction' meant.").

${ }^{74}$ Additionally, Justice Scalia and others have argued that subsequent legislative action or inaction is irrelevant to a statute's meaning. Eskridge, supra note 9, at 1405 n.215.

${ }^{75}$ There may be specific cases in which subsequent action or inaction by the legislature does provide relatively strong evidence of legislative acquiescence, for example if Congress has a clear opportunity to respond to the Court's decision but declines to do so, such as when it reenacts the statute with changes or when it enacts a related statute with the same language. In such cases, it would be sensible to reaffirm the earlier decision. But this requires careful case-specific analysis and would not support a general presumption in favor of precedent even in the narrow category of cases that we have already identified. Thus, in order to make sense of the super-strong presumption of statutory stare decisis, we must define the class of cases to which it reasonably applies so narrowly that the "rule" ceases to be of much use.

${ }^{76}$ Eskridge, supra note 9, at 1369. 
Finally, as scholars have shown, the legislative-acquiescence argument is problematic because even when Congress does override an earlier decision of the Court, subsequent judicial rulings tend to construe such overrides narrowly, seeking to preserve as much of the supposedly overridden precedent as possible-and more than may be reasonable. ${ }^{77}$ There are different reasons for this. First, drafting and passing a legislative override is no simple task. How narrow or broad should the override be? Should the override respond to and "fix" the Court's broad jurisprudence in the relevant area in order to create a consistent and coherent legal landscape, or should it focus only on the case itself and let the courts sort out the inconsistencies and anomalies that may result?78 Faced with these questions, legislators produce statutory overrides that introduce new questions and vagueness into the law. ${ }^{79}$ Second, when lower courts face the resulting questions, they must reconcile the new legislative enactments with any part of the precedential opinion and related opinions from the Supreme Court that have not been explicitly overridden. ${ }^{80}$ Lower courts typically end up preserving more of the overridden precedents than Congress intended or expected. ${ }^{81}$ This pattern undermines the argument for heightened deference to statutory precedent, which assumes that Congress can readily "undo" precedents of which it disapproves.

\section{THE RELIANCE APPROACH TO PRECEDENT}

There is an alternative justification for adhering to precedent that offers a far stronger descriptive and normative account of the doctrine, which I call the reliance approach. According to this approach, courts should defer to their precedents in order to avoid

77 Widiss, supra note 67 , at 531-34.

78 Id. at 517 (arguing that Congress should strive to clarify the extent to which it disagrees with a prior judicial interpretation, while courts should "recognize that in enacting an override, Congress has the power to reinterpret the preexisting statutory language as well as to add new statutory language").

79 Id. at $514-15$.

80 Id.

81 Id. 
undermining the reliance interests that the public has justifiably developed based on those precedents. In this Part, I introduce this approach by relating the core function of the courts to the doctrine of precedent. I then suggest that the relative institutional competencies of the judiciary and the legislature explain why the former should defer to precedent while the latter is free to reject it. Finally, I show that several leading scholars and judges have anticipated the reliance approach or offered related accounts, but that previous treatments have not comprehensively or convincingly explored the approach's justifications and implications.

\section{A. THE CORE FUNCTION OF LAW AND COURTS}

A basic function of law and judicial opinions is to allow members of society to predict the future, thereby guiding them on how to order their lives. ${ }^{82}$ That is, law and judicial opinions generate understanding on the part of the governed-including private citizens, organizations, and public officials and bodies-as to what is required of them, how they may (or must) act, and how to avoid and resolve disputes. When members of society take action based on understandings generated from judicial opinions, those decisions generate reliance interests.

Judges, like other lawmakers, consequently exert substantial control over our lives, as their opinions require or encourage us to make critical and often costly investments-of money, time, talent, and other resources-that we otherwise would not have made. But this power and the benefits it provides come at a price: courts must constrain themselves to adhere to their opinions. Otherwise, judicial opinions lose their predictive power, and we would be justified in discounting them in deciding how to act. The central function of precedent, then, is that it protects the legitimate reliance interests of the public, and if we wish for judicial opinions to affect parties other than those in the specific case being decided, then we must insist on the doctrine of precedent. ${ }^{83}$ In this way, a

82 Schauer, supra note 1, at 597.

s3 See Max Minzner, Saving Stare Decisis: Preclusion, Precedent, and Procedural Due 
core function of the courts depends on the doctrine of precedent, and this is why precedent is a central organizing feature of our legal order.

What this means in practical terms is that even when judges believe that an earlier case was wrongly decided, they must discipline themselves to adhere to the principles announced in that case, in the absence of extraordinary circumstances. Naturally, judges may be tempted to adhere to precedent as a general rule but to reject it in what they view to be particularly egregious cases. They might intuit, even correctly, that such limited and judicious rejections of precedent would not cause our legal order to collapse. But such departures from precedent would still raise moral concerns: if people have justifiably relied on past judicial decisions to their detriment, then their reliance interests would be undermined and the investments they made as a result of such judicial guidance would be jeopardized. As we have seen, by adhering to precedent, judges induce-indeed, force-the public to act in reliance on judicial pronouncements. For a judge to then turn around and frustrate those reliance interests would be like committing a sort of fraud. In this way, the doctrine of precedent may be best understood as akin to promissory estoppel in contract law. ${ }^{84}$

To concretize the argument, consider my mother's approaching retirement. ${ }^{85}$ For the past several years, she has paid money into the Social Security system and invested in retirement accounts. Having done so, she has spent the bulk of her life secure in the knowledge that she has prepared for retirement (recognizing, of course, that some basic risks exist in any investing strategy). This has allowed her to plan her life and caused her to spend her nonretirement funds in any number of ways. As she approaches retirement, she reasonably assumes she will have resources

Process, 2010 B.Y.U. L. REv. 597, 621 ("We accept the impact on third parties as part of the effort to create legal rules on which people can rely.").

${ }^{84}$ Estoppel means (1) there is "[a] promise which the promisor should reasonably expect to induce action or forbearance on the part of the promisee or third person" and (2) "which does induce such action or forbearance." RESTATEMENT (SECOND) OF CONTRACTS $§ 90$ (1981).

85 Alas, I do not know how to cite to my mother's retirement planning. 
available to her from the Social Security system and from her retirement accounts. A primary reason that my mother has been able to organize her life in this way is that she has (albeit unbeknownst to her) relied on various Supreme Court decisions that allowed Congress to institute the Social Security system and permitted financial markets to develop in a way that makes investments in retirement accounts possible. ${ }^{86}$

Suppose that each of our contemporary Supreme Court Justices believes that these earlier decisions were wrong. Assume, too, that every legal scholar in the nation agrees with them. In other words, the strongest case possible can be made that the precedents lack merit. Under these circumstances, the Court may be inclined to overturn these precedents should appropriate cases raising the issues present themselves. But what would happen if the Court did so? In a word, chaos. My mother's years of careful planning, career decisions, financial choices, and reasonable expectations about the future would be nullified in an instant. Could she retire when she planned? Could she ever retire? Are her investments worthless? Does she even still have a bank account? Can she buy food tomorrow? Can anyone? And this chaos would be the Court's fault.

In short, the most fundamental reason that precedent matters is that people reasonably rely on the courts and order their affairs accordingly. It would be immoral for the courts to say "oops," claim a do-over, and then do violence to those people whose actions have been induced by the courts themselves. ${ }^{87}$

86 See, e.g., Helvering v. Davis, 301 U.S. 619 (1937) (upholding the Social Security Act); Legal Tender Cases, 79 U.S. (12 Wall.) 457 (1871) (upholding the constitutionality of paper money).

87 It is impossible to consider the question of precedent without confronting Casey and $R o e$, the cases that focused scholarly and public attention on the precedent question to a greater degree than any others.

The plurality in Casey addressed the reliance value of Roe. It first considered several ways in which Roe did not induce reliance on the part of the public:

Abortion is customarily chosen as an unplanned response to the consequence of unplanned activity or to the failure of conventional birth control, and except on the assumption that no intercourse would have occurred but for Roe's holding, such behavior may appear to justify no reliance claim. Even if reliance could be claimed on that unrealistic 


\section{B. RELATIVE JUDICIAL AND LEGISLATIVE COMPETENCIES}

Any credible justification for the doctrine of precedent must distinguish between courts and legislatures. That is, to be persuasive, a rationale must account for why a court should defer to its precedents but a legislature is free to reject its earlier laws. ${ }^{88}$ At first glance, this requirement appears to challenge the reliance approach. After all, people surely organize their lives around statutory law to at least as great a degree as they do around judicial precedents. If, as I have argued, the morality of a legal

assumption, the argument might run, any reliance interest would be de minimis.

Planned Parenthood of Se. Pa. v. Casey, 505 U.S. 833, 856 (1992) (plurality opinion).

However, the plurality ultimately rejected this view on the grounds that for two decades of economic and social developments, people have organized intimate relationships and made choices that define their views of themselves and their places in society, in reliance on the availability of abortion in the event that contraception should fail. The ability of women to participate equally in the economic and social life of the Nation has been Id. at 856 . facilitated by their ability to control their reproductive lives.

The best way to conceptualize these arguments is to ask what would happen if Roe and Casey were overturned tomorrow. Most obviously and immediately, those medical professionals who have devoted their medical practices to providing access to safe and legal abortions would find their reliance interests undermined (though they may be able to provide other healthcare services to women). Likewise, women who became pregnant before the Court overturned $R o e$ and Casey could reasonably argue that their sexual practices and birth control choices were made with the assumption that abortion services would be available to them.

More broadly, however, we would need to consider the extent to which women (and men) have organized their lives and livelihood around the assumption that access to abortion would be available to them. Specifically, have they invested in their education, relationships, and careers in ways that would have been different had Roe been decided differently, much like my mother relies on the Social Security system? This is what the plurality seems to argue, albeit vaguely, and this is what should control the question.

My intuition is that different people-including different judges and scholars-will assess the reliance interests differently. But this question is amenable to careful empirical inquiry, and even if such inquiry would not fully resolve the matter, applying the reliance lens allows us to identify the relevant questions and to channel the judicial inquiry and the locus of judicial judgment to this common ground.

Finally, it is possible that as the Supreme Court's protection of abortion rights appears to erode, and as states impose increasingly restrictive laws on the availability of abortion services, we may experience a shift in the public's reliance-based investment on the continued vitality of Roe and Case. See infra Part V.A and note 243.

88 See supra Part II.B.3. 
system demands that people's reliance interests be protected, then why is a legislature free to change the law as it sees fit? The answer to this question lies in the relative institutional competencies and capabilities of courts and legislatures.

Judges are often poorly situated to mitigate the effects of any reliance interests that have accrued due to their passed decisions. ${ }^{89}$ Consider again Social Security. If the Supreme Court were faced with a constitutional challenge to the Social Security system, the Justices' choice would be binary: uphold the Social Security system or strike it down as unconstitutional. If they were to strike it down, there is little they could do to mitigate the chaotic effects of the decision. They could not, for example, phase out Social Security over a number of years, slowly raise and then eliminate the retirement age, or ensure that those who have paid in will be able to participate in Social Security and only eliminate it for those who have not yet participated. ${ }^{90}$ The Constitution does not grant courts these policymaking powers, and they lack the democratic pedigree to wield them.

But let us even assume that the Court could institute such policymaking measures that would mitigate the chaotic effects of such a ruling. ${ }^{91}$ Even so, they are ill-suited to the task. Courts typically focus on very specific legal questions and very specific facts from the past; it is beyond their brief and ability to anticipate

89 See, e.g., Kozel, supra note 13 (manuscript at 20-21) ("The Supreme Court's powers to deal with legal change are limited. The Court cannot go ahead with overturning a precedent but order that the gains resulting from the reversal be divvied equally among the winners and losers. Nor can it depend on those who benefit from legal changes to make voluntary payments to the losers in order to dull the sting. Prospective overruling is a potential middle ground, but the Court has recently expressed disfavor for that approach. And even prospective overruling is an incomplete tool, providing little help to those who have made forward-looking investments on the assumption that a certain legal rule will remain binding into the future." (footnotes omitted)).

90 See infra note 93.

91 Some Justices have attempted to do so in rare cases. See, e.g., Grutter v. Bollinger, 539 U.S. 306, 342 (2003) (announcing a sort of Court-imposed sunset provision for raceconscious admissions programs); Bush v. Gore, 531 U.S. 98, 109 (2000) (clarifying that the decision applies only to the facts at hand); Flood v. Kuhn, 407 U.S. 258, 293 (1972) (Marshall, J., dissenting) (arguing that the Court should overrule its precedent but make the decision apply prospectively). All of these are attempts to ameliorate the mischief that a decision may cause and to allow people to plan accordingly. 
all of the ways in which a rejection of precedent may create waves in the law and undermine reliance interests. Further, even if they could make such predictions, courts-particularly appellate courts-do not have the ability to call witnesses to provide testimony as to how it may effectively craft a policy that would mitigate the effects of the ruling, and they have no basis for evaluating such arguments. And even if they were open to doing so, given the distinctive position of the courts as being responsive to cases and controversies, they may have little opportunity to revise the policies they mandate should experience prove them unwise or unworkable.

In contrast, the legislature is well positioned for these tasks. The job of the legislature is to create forward-looking laws. To do so, legislators have many tools at their disposal, including the ability to deliberate for as long as they wish, to consider testimony from those with expertise, to introduce comprehensive legal frameworks, and to revisit and adjust laws as necessary. Additionally, legislators are democratically accountable and therefore face political constraints on their ability to pass laws that would substantially undermine the reliance interests of the public. Further, the Framers made it difficult even for the legislature to pass new laws precisely because they wanted to foster social stability and thus to protect reliance interests. ${ }^{92}$ It is no surprise, therefore, that all legislative proposals to modify the Social Security system - even those that call for the most radical transformations-include mechanisms to protect the reliance interests of those who have acted in reliance on the status quo. ${ }^{93}$

92 The Federalist No. 62, at 379 (James Madison) (Clinton Rossiter ed., 1961) ("The internal effects of a mutable policy are still more calamitous. It poisons the blessing of liberty itself. It will be of little avail to the people, that the laws are made by men of their own choice, if the laws ... undergo such incessant changes that no man, who knows what the law is to-day, can guess what it will be to-morrow.").

93 Leading proposals from both sides of the political aisle recognize the importance of reliance interests. See, e.g., THE HERITAge Found., SAVING THE AMERICAN DREAM: THE Heritage Plan to Ftx the DebT, Cut SPENDing, aNd Restore Prosperity 7-13 (Stuart M. Butler et al. eds., 2011), http://thf_media.s3.amazonaws.com/2011/pdf/sr0091.pdf (arguing for a solution that takes into account both "promises past Congresses have made" to current generations and also "the consequences their children and grandchildren will suffer if these promised benefits remain untouched," to develop a "[p]redictable [b]enefit [t]hat [p]rovides 
Thus, unlike the courts, the legislature is unlikely to wholly upset reliance interests, and it has the tools necessary to craft policies that mitigate the costs of radical policy changes. In short, the Legislature need not adhere to precedent because it has other-better-ways of accounting for, and constraints on its ability to upset, reliance interests. ${ }^{94}$ For courts, the doctrine of precedent provides the central mechanism for protecting these interests.

\section{SCHOLARLY AND JUDICIAL PRECURSORS}

The reliance approach is not entirely novel. Judges and scholars have alluded to related principles, though they have never offered a sustained account of or consistently applied a reliance approach. Likewise, scholars and judges have not explored the moral and jurisprudential foundations of this approach, nor have they taken it seriously enough to trace its implications and how they differ from the implications of alternative justifications for precedent. In other words, the reliance approach finds latent support and antecedents within legal discourse, but judicial and scholarly treatment of the subject is far from complete.

Perhaps the Supreme Court case that best expresses the reliance approach is United States $v$. Title Insurance \& Trust Co., in which the United States sued on behalf of Native Americans claiming land rights. ${ }^{95}$ Without considering the substantive merits of the case, the Court affirmed an earlier precedent:

The [earlier] decision was given twenty-three years ago and affected many tracts of land.... In the

[e]conomic [s]ecurity"); GENe SPERLING, A PRogressive Framework FOR Soclal SECURITY REFORM 4 (2005) (on file with author) (arguing that any Social Security reform must start from a place of protecting retirement security).

${ }_{94}$ A difficult question arises when legislatures do not use the tools at their disposal to protect reliance interests. For example, consider the possibility that the legislature may institute new taxes that have retroactive effect, thereby frustrating reliance interests. Is this acceptable behavior? I leave this as an open question that requires further consideration.

95265 U.S. 472, 481 (1924). 
meantime there has been a continuous growth and development in that section, land values have enhanced, and there have been many transfers. Naturally there has been reliance on the decision.... It has become a rule of property, and to disturb it now would be fraught with many injurious results. ${ }^{96}$

This case captures the reliance approach to precedent fairly well; its thrust is that it is problematic for courts to undo decisions that others have reasonably relied upon and invested heavily in as a result.

Unfortunately, this case and others that share its orientation ${ }^{97}$ have not become a touchstone for courts in deciding whether to adhere to precedent. Judicial citations to this case usually have nothing to do with precedent; 98 those that do cite it as offering a justification for adhering to precedent usually relate specifically to the field of property law; ${ }^{99}$ when it is cited as a broader principle justifying adherence to precedent, it is typically offered as simply one among several reasons for doing so; ${ }^{100}$ its foundational

96 Id. at 486. The Court went on to eloquently describe one of the differences between courts and legislatures' ability to resolve problems such as these:

Legislatures may alter or change their laws, without injury, as they affect the future only; but where courts vacillate, and overrule their own decisions on the construction of statutes affecting the title to real property, their decisions are retrospective and may affect titles purchased on the faith of their stability. Doubtful questions on subjects of this nature, when once decided, should be considered no longer doubtful or subject to change.

Id. at 486-87 (internal quotation mark omitted).

97 See, e.g., Allied-Bruce Terminix Cos. v. Dobson, 513 U.S. 265, 272 (1995) (citing reliance in affirming precedent); Patterson v. McLean Credit Union, 491 U.S. 164, 172-75 (1989) (same); Summa Corp. v. California ex rel. State Lands Comm'n, 466 U.S. 198 (1984) (same).

98 A Westlaw search reveals that this case has been cited roughly 100 times in other cases, and roughly fifty times in scholarly literature, though most of these citations do not relate to the issue of precedent but rather to other, unrelated aspects of the case.

99 E.g., Summa Corp., 466 U.S. at 208-09.

100 A typical "examination" of the application of precedent featuring Title Insurance looks like this:

Stare decisis is the preferred course because it promotes the evenhanded, predictable, and consistent development of legal principles, fosters reliance 
jurisprudential justifications have never been explored; and its broader implications are never considered. In other words, the case law has identified the significance of reliance in the law of precedent but has not internalized its principles or applied it in a consistent or considered way.

The bulk of the scholarship relating to the reliance approach is likewise embryonic and thus incomplete. ${ }^{101}$ For example, Michael Gerhardt argues that some precedents have attained the status of "super precedent." This category, he says, includes

on judicial decisions, and contributes to the actual and perceived integrity of the judicial process. See Vasquez v. Hillery, 474 U.S. 254, 265-266 (1986). Adhering to precedent "is usually the wise policy, because in most matters it is more important that the applicable rule of law be settled than it be settled right." [sic] Burnet v. Coronado Oil \& Gas Co., 285 U.S. 393, 406 (1932) (Brandeis, J., dissenting). Nevertheless, when governing decisions are unworkable or are badly reasoned, "this Court has never felt constrained to follow precedent." Smith v. Allwright, 321 U.S. 649,665 (1944). Stare decisis is not an inexorable command; rather, it "is a principle of policy and not a mechanical formula of adherence to the latest decision." Helvering v. Hallock, 309 U.S. 106, 119 (1940). This is particularly true in constitutional cases, because in such cases "correction through legislative action is practically impossible." Burnet v. Coronado Oil \& Gas Co., supra, at 407 (Brandeis, J., dissenting). Considerations in favor of stare decisis are at their acme in cases involving property and contract rights, where reliance interests are involved, see Swift \& Co. v. Wickham, 382 U.S. 111, 116 (1965); Oregon ex rel. State Land Bd. v. Corvallis Sand \& Gravel Co., 429 U.S. 363 (1977); Burnet v. Coronado Oil \& Gas Co., supra, at 405-411 (Brandeis, J., dissenting); United States v. Title Ins. \& Trust Co., 265 U.S. 472 (1924); The Genesee Chief v. Fitzhugh, 12 How. 443, 458 (1852); the opposite is true in cases such as the present one involving procedural and evidentiary rules.

Payne v. Tennessee, 501 U.S. 808, 827-28 (1991) (citations and alterations in original).

${ }^{101}$ A thoughtful discussion of the Title Insurance case and its implications is featured in Thomas R. Lee, Stare Decisis in Economic Perspective: An Economic Analysis of the Supreme Court's Doctrine of Precedent, 78 N.C. L. REV. 643, 661-63 (2000). Lee develops an economic model for deciding when precedent ought to bind courts, focusing on the costs imposed by deviation from precedent. He suggests that precedents concerning property ownership are especially strong because of the nature of the reliance interests that ensue. I am not certain that this particular conclusion is warranted, but the article is provocative and touches on themes explored herein. Lee's article, however, limits itself (by design) to an economic consideration of the value of precedent and does not explore the ways in which these economic concerns relate to the judicial role. Likewise, he does not extend his analysis beyond the prototypical case of horizontal precedent. This is not meant to criticize Lee's article, which cogently mines some of the same ground as mine. I mean only to suggest that Lee's approach and interests lie in a different arena from mine. 
those constitutional decisions in which public institutions have heavily invested, repeatedly relied, and consistently supported over a significant period of time. Super precedents are deeply embedded into our law and lives through the subsequent activities of the other branches.... Super precedents are the clearest instances in which the institutional values promoted by fidelity to precedent-consistency, stability, predictability, and social reliance-have become irredeemably compelling. ${ }^{102}$

Similarly, Daniel Farber suggests that "bedrock precedents" should be retained to achieve the "stable framework for government" that a constitution is designed to establish. ${ }^{103} \mathrm{He}$ describes precedents that upheld the constitutionality of New Deal reforms, tax and spending programs, federal control of the economy, and administrative agencies, as well as rulings that incorporated the Bill of Rights into the Fourteenth Amendment and mandated desegregation, as "omelettes [that] cannot be unscrambled today"104 because trying to do so would lead to "the kind of uncertainty and instability that constitutions... are designed to avoid." 105

The theory of precedent advanced by Gerhardt and Farber resonates with but does not perfectly replicate the reliance approach. For instance, Gerhardt and Farber privilege constitutional precedents over common law and statutory precedents, ${ }^{106}$ whereas the reliance approach does not; after all, the public's reliance interests do not necessarily track the category of precedent. ${ }^{107}$ Relatedly, Gerhardt and Farber only begin to

\footnotetext{
102 Gerhardt, supra note 8, at 1205-06.

103 Farber, supra note 11, at 1180.

${ }_{104} I d$.

105 Id. at 1181 .

106 Id. at 1180; Gerhardt, supra note 8, at 1205.

${ }_{107}$ It is not clear why Gerhardt and Farber seem to believe that constitutional precedents deserve privileged status. Indeed, as Eskridge and Ferejohn argue, in today's society, statutes are a more central and robust source of public policy than is the Constitution. See generally WILLIAM N. ESKRIDGE JR. \& JOHN FEREJOHN, A REPUBLIC OF STATUTES: THE NEW AMERICAN CONSTITUTION (2010).
} 
explore the implications of their approaches-finding some famous constitutional cases qualify as super or bedrock precedents and others do not ${ }^{108}$-without considering more nuanced applications of their central insight. Finally, their arguments do not explain why the judicial and legislative treatments of precedent should differ.

All of these deficits stem from a failure to explore the jurisprudential foundations of their approach. Indeed, to the extent that they do reflect on the deep values that operate in this area, they miss important features of the reliance approach. Gerhardt considers cases to be super precedents when other branches of government invest and rely on them, ${ }^{109}$ and Farber considers cases to be bedrock cases when they stabilize government institutions. ${ }^{110}$ In contrast, the reliance approach focuses primarily on the public's investment in a decision. Even so, Gerhardt and Farber's focus on principles like stability and reliance is shared by the reliance approach.

Perhaps the most important contribution to the literature concerning the intersection between reliance and precedent is Randy Kozel's forthcoming article, Precedent and Reliance. ${ }^{111}$ Kozel likewise finds the literature concerning reliance undertheorized $^{112}$ and suggests that there is an abiding tension between the Supreme Court's rhetorical commitment to the reliance-protecting and stability-inducing aspects of deference to precedent and its repeated admonition that precedent does not actually operate to bind courts and is not "an inexorable command" or "a promise." 113 As a result of this tension, Kozel suggests that

108 Gerhardt discusses several well-known cases that he considers to be super precedent, such as Knox v. Lee, 79 U.S. (12 Wall.) 457 (1871), a case that upheld the constitutionality of paper money, and Youngstown Sheet \& Tube Co. v. Sawyer, 343 U.S. 579 (1952), a separation of powers decision, while also mentioning several famous cases that he does not believe fully qualify as super precedent, such as Miranda v. Arizona, 384 U.S. 436 (1966), and Wickard v. Filburn, 317 U.S. 111 (1942). Gerhardt, supra note 8, at 1213-19.

109 Id. at 1205.

110 Farber, supra note 11, at 1180 .

111 Kozel, supra note 13.

112 Id. (manuscript at 9-10).

113 Id. (manuscript at 2). Kozel poignantly quotes Brandeis's famous statement that "in most matters it is more important that the applicable rule of law be settled than it be 
protecting those who relied on earlier decisions is fundamentally not the justification for the doctrine of precedent. Rather, he suggests that precedent simply "operates as a buffer against dramatic change, nothing more and nothing less," and that "[t]he concept of reliance serves as a proxy for the disruption likely to attend a judicial overruling." 114

While Kozel's approach shares much with mine, ultimately our projects are different. Whereas he essentially rejects reliance interests as a justification for deference to precedent in light of the Court's inconsistency in adhering to precedent, I steadfastly maintain that traditional reliance interests must be the core of precedent doctrine in order to protect the judiciary's moral standing. ${ }^{115}$ To the extent the Supreme Court has rejected precedent, I suggest that it has done so because reliance interests are (1) either not present or are outweighed by other factors ${ }^{116}$ or (2) precisely because reliance has been undertheorized and not fully internalized by judges as a basis for precedent. Further, like most scholars, Kozel limits his study to the Supreme Court. In contrast, I consider the operation of the reliance approach in lower courts and its vast implications for other actors in the legal system.

In addition to legal scholars like Farber, Gerhardt, and Kozel, philosophers as disparate as F.A. Hayek, Joseph Raz, Lon Fuller, and John Rawls have also identified the critical role that public certainty, expectations, and reliance concerning the law play in the

settled right," and simultaneously notes that Brandeis insisted that the Court must overturn some kinds of precedent. Id. (manuscript at 4). Kozel goes on to demonstrate just how inconsistent the Court has been on this score. See id. (manuscript at 12) (noting the Court's "pronounced ambivalence").

114 Id. (manuscript at 19).

115 Further, it is unclear to me why Kozel insists that a tension within a doctrine is reason to discount it. Legal doctrine is full of balancing tests that feature embedded tensions. Different judges may come to different conclusions about the appropriate balance and thus vote differently, but that does not devalue the test, which still performs the important function of identifying the relevant considerations and channeling the task of judging onto agreed-upon grounds.

116 I explore such cases in Part IV.A.1-2, infra. In short, one reason that Courts may decline to adhere to precedent is that reliance has been negligible. Under the reliance approach, this is fully justified. 
development of a just legal order. For example, Hayek-ever the libertarian and therefore attuned to the interests of the individual-maintained that "[s]tripped of all technicalities, [the rule of law] means that government in all its actions is bound by ... rules which make it possible to foresee with fair certainty how the authority will use its coercive powers in given circumstances and to plan one's individual affairs on the basis of this knowledge."117

Like Hayek, Rawls viewed this rule-of-law principle as "closely related to liberty."118 A legal system can only be just, he suggested, when it "establish[es] a basis for legitimate expectations... [and] constitute[s] grounds upon which persons can rely on one another and rightly object when their expectations are not fulfilled."119 Further, if rules are unstable or unclear, "the boundaries of men's liberties" are unsure, ${ }^{120}$ and "the citizen does not know how he is to behave." 121 Fuller also identified predictability and stability as central to a just legal system. ${ }^{122} \mathrm{He}$ went so far as to argue that a system that fails to meet these requirements "is not properly called a legal system at all." 123

Although Raz stressed that strict or perfect adherence to Hayek's (and by implication Rawls's and Fuller's) vision of the rule of law is impossible and, indeed, sometimes undesirable in light of competing values, ${ }^{124}$ he too emphasized reliance-related values,

117 F.A. HAYEK, THE ROAD TO SERFDOM 80 (fiftieth anniversary ed. 1994) (1944).

118 JOHN RAWLS, A THEORY OF JUSTICE 207 (rev. ed. 2000) (1971).

119 Id.

120 Id.

121 Id. at 209.

122 LON L. FULleR, THE MORALITY OF LAW 39 (rev. ed. 1969) (1964). Fuller famously identified eight features that would render a legal system immoral. These are (1) inconsistent adjudication due to the lack of law; (2) "failure to publicize" the law; (3) retroactive laws; (4) lack of clarity in the law; (5) contradictory laws; (6) legal duties that the regulated community cannot comply with; (7) lack of stability in the law due to constant revision; and (8) inconsistent application and interpretation of the law. Id. These elements of a moral legal order all share in common that they impose predictability on the law and thereby generate public expectations and allow people to rely on the law.

123 Id.

124 JOSEPH RAZ, ThE AUTHORITY OF LAW: EsSAYS ON LAW AND MORALITY 228 (1979) (arguing, contra Hayek, that "the rule of law is just one of the virtues that law should possess ... [and] [i]t has always to be balanced against competing claims of other values"). 
agreeing that "people need to know the law not only for short-term decisions ... but also for long-term planning. ... Stability [in the law] is essential if people are to be guided by law in their longterm decisions." 125

None of these thinkers has explicitly linked reliance with precedent, but the implications are clear. Indeed, their writings signal that precedent is not merely a single doctrine within the law-one among many-but rather is a singular doctrine that goes to the heart of law's morality and claim to justice. This is so precisely because adherence to precedent stands at the center of a legal order that protects, and thus facilitates, reliance. More so than the other justifications for precedent, then, the reliance approach to precedent explains why precedent features so heavily in legal discourse.

In sum, although the reliance approach to precedent has never been fully developed or consistently applied by judges or scholars, it finds powerful-if inchoate-support within the judicial and scholarly conception of just and moral law.

\section{IMPLICATIONS: LIMITING AND EXPANDING PRECEDENT}

Thus far, I have introduced and developed the jurisprudential basis for the reliance approach to precedent. In this Part, I examine the far-reaching implications of this approach. I first consider some of the ways in which it limits the universe of cases that ought to be considered as having precedential value. I then consider how the reliance approach radically expands the kinds of sources that we ought to consider as precedent. I also identify several ways in which the current doctrine concerning precedent has embedded elements of the reliance principles, but only in embryonic form. Thus, close inspection reveals that the reliance approach has both descriptive and normative power.

125 Id. at 214-15. 


\section{A. LIMITING PRECEDENT}

Despite its fundamental and powerful moral imperative, the reliance approach suggests certain limits on precedent's reach and force. Specifically, some kinds of judicial decisions should be viewed as nonprecedential altogether, while others should be seen as having limited precedential value. In the former set of cases, judges should be free to discount previous decisions if they are convinced that the cases were wrongly decided. In the latter, judges should place less value on precedent-based arguments. Thus, in contrast to the alternative approaches to precedent, the reliance approach substantially limits the universe of cases that should be considered as precedential.

Simply stated, courts should not defer to precedents that do not give rise to substantial reliance interests. Judges should thus apply a sort of reliance test to determine whether a case should be viewed as having presumptive precedential force. If rejecting that case would not frustrate substantial reliance interests among the public, then judges are free to do so. I identify three categories in which precedential force should be denied or limited.

1. Category 1: Cases That Cannot Generate Reliance Interests. Some cases that should lack precedential force are easy to spot because they are not the kinds of cases that induce reliance. For example, the majority in the Heller gun-rights case correctly rejected the argument that it should adhere, simply on the grounds of precedent, to the pronouncement in the 1939 case United States $v$. Miller ${ }^{126}$ that the Second Amendment does not protect individual gun ownership rights. ${ }^{127}$ After all, it is difficult to identify any group of people who had in any meaningful sense organized their lives around the Miller decision. There were surely those who were disappointed by the Miller decision and who would have, in its absence, chosen to possess weapons. But by

\footnotetext{
126307 U.S. 174 (1939).

127 District of Columbia v. Heller, 554 U.S. 570, 625 (2008). To clarify, I do not here take a stand on whether the majority in Heller correctly interpreted the Second Amendment. I mean only to say that the existence of the earlier Miller decision was not, in itself, a substantive reason to rule one way or another.
} 
allowing greater gun rights in Heller, the Court did not reorder social arrangements or meaningfully disrupt reliance interests. ${ }^{128}$

A similar pattern (notably from the other side of the proverbial political aisle) is presented by Lawrence $v$. Texas, which overturned the earlier decision of Bowers v. Hardwick. ${ }^{129}$ Bowers had held that a state law penalizing sodomy did not run afoul of substantive due process. ${ }^{130}$ As with Miller, it is hard to envision how people had organized their lives around Bowers in a manner with which Lawrence interfered. Even those (if there were any) who organized their sexual lives in keeping with antisodomy laws did not have anything meaningfully invested in the decision; they were now simply free to consider expanding their sexual practices. Thus, when faced with the opportunity to reconsider the question in Lawrence, the Court reasonably dispensed with precedent and reasoned through the question substantively. ${ }^{131}$

Consider also one of the hot-button issues of the moment, the battle over same-sex marriage. ${ }^{132}$ In the 1971 case Baker $v$. Nelson, the Supreme Court dismissed for want of a substantial

128 Indeed, to the chagrin of many gun-rights advocates, the Court was particularly careful not to open the doors to a wholesale assault on gun-control laws. In the course of its opinion, the Court went beyond the facts of the Heller case and stated that its ruling would not interfere with many restrictions on gun ownership. Id. at 626-27. One way to understand this statement is that, consistent with the reliance interests animating the doctrine of precedent, the Court was concerned about the potential of its opinion to create chaos in the lower courts.

129 Lawrence v. Texas, 539 U.S. 558, 578 (2003), overruling Bowers v. Hardwick, 478 U.S. 186 (1986).

130 Bowers, 478 U.S. at 196.

131 One might argue that Justice O'Connor's equal-protection-based concurrence in Lawrence provided an even better basis for the decision under a reliance approach to precedent, for two reasons. First, Justice O'Connor's concurrence would not have directly overturned Bowers because it was limited to laws that treated sexual acts between members of the same sex differently from those between members of the opposite sex. 539 U.S. at 582 (O'Connor, J., concurring in the judgment). Second, the novel principle articulated by Justice Kennedy in his majority opinion that moral beliefs alone are not sufficient to serve as a rational basis for a law may have unforeseen consequences on a host of other laws, as Justice Scalia's dissent argued. Id. at 598 (Scalia, J., dissenting). As such, Justice Kennedy's opinion may interfere with reliance interests in other areas of the law. Justice O'Connor's concurrence does not have the same reach.

132 See Hollingsworth v. Perry, 133 S. Ct. 786 (2012), granting cert., Perry v. Brown, 671 F.3d 1052 (9th Cir. 2012); United States v. Windsor, $133 \mathrm{~S}$. Ct. 786 (2012), granting cert., 699 F.3d 169 (2d Cir. 2012). 
federal question a challenge to a Minnesota law that limited marriage to opposite-sex couples. ${ }^{133}$ In recent years, the courts have begun to consider new challenges to such laws. ${ }^{134}$ If the Supreme Court decides this issue in Perry or Windsor, one question will be whether the Justices should adhere to Baker on account of precedent. 135 The reliance approach suggests they should not. As with Miller and Bowers, a great many people have been affected by the Court's decision in Baker: same-sex couples who want to marry cannot, political discourse has organized itself around the debate over same-sex marriage, and, of course, those who oppose same-sex marriage would be disappointed if Baker were rejected in the future. But it is difficult to see how the Court rejecting Baker would impose new costs on society beyond those associated with simple disagreement-costs that will be incurred however the Court rules in Perry and Windsor and regardless of whether Baker had ever existed. ${ }^{136}$ As such, the existence of the Baker decision provides no independent basis for the Court to reject challenges by advocates of same-sex marriage, and the Court should accord no precedential weight to it. Instead, it should decide these cases purely on their constitutional merits.

Collectively, these examples suggest that the reliance approach to precedent tends to allow the Court to increase its protection of

133 Baker v. Nelson, 191 N.W.2d 185, 185 (Minn. 1971), appeal dismissed, 409 U.S. 810 (1972).

134 See, e.g., Massachusetts v. U.S. Dep't of Health \& Human Servs., 682 F.3d 1 (1st Cir. 2012); Perry v. Brown, 671 F.3d 1052 (9th Cir. 2012), cert. granted, Hollingsworth, $133 \mathrm{~S}$. Ct. 786 (No. 12-144); Citizens for Equal Prot. v. Bruning, 455 F.3d 859 (8th Cir. 2006). It is worth noting that lower courts have adopted different approaches to the question whether Baker constitutes binding precedent. Compare, e.g., McConnell v. United States, 188 F. App'x 540, 542 (8th Cir. 2006) (following Baker); Wilson v. Ake, 354 F. Supp. 2d 1298, 1304 05 (M.D. Fla. 2005) (same); Andersen v. King County, 138 P.3d 963, 999 (Wash. 2006) (same), and Langan v. St. Vincent's Hosp. of N.Y., 802 N.Y.S.2d 476, 478 (N.Y. App. Div. 2005) (same), with e.g., Smelt v. County of Orange, 374 F. Supp. 2d 861, 872 (C.D. Cal. 2005), aff'd in part and vacated in part, 447 F.3d 673 (9th Cir. 2006) (Baker not binding), and In re Kandu, 315 B.R. 123, 138 (Bankr. W.D. Wash. 2004) (same).

135 E.g., Transcript of Oral Argument at 12-13, Hollingsworth, 133 S. Ct. 786 (No. 12-144).

${ }^{136}$ In other words, folks will argue bitterly about whether the Court's decisions in Perry and Windsor are correct, but they will do so regardless of which way the Court rules, and the Court's decision to rule consistently or inconsistently with Baker will not feature in the public consequences. 
liberties at the expense of precedent, but not as easily restrict them. That is, when precedents are restrictive, as in Miller, Bowers, and Baker, they are not likely the sort upon which people organize their lives. In contrast, opinions that expand protections of liberty, like a case requiring recognition of same-sex marriage, are much less easily undone because of the reliance-and consequent investment-they induce. ${ }^{137}$

2. Category 2: Cases That Could but Do Not Generate Reliance Interests. There are additional circumstances in which cases should be stripped of precedential force. These are cases that could have given rise to reliance interests but for whatever reason have not. In contrast to the cases in the first category, which may be identified simply by considering their substance, cases in this category may only be recognized after careful consideration of their practical effects.

Consider, for example, Korematsu $v$. United States, in which the Court in famously affirmed the legality of the federal government's decision to detain Americans of Japanese descent in internment camps during World War II. ${ }^{138}$ Unlike with respect to Miller, Bowers, and Baker, one might imagine that Korematsu could have given rise to substantial reliance interests on the part of the government. For example, the government could have created long-term plans for the internment of particular ethnic groups in the event of war with other countries. Likewise, it could have constructed permanent internment facilities and a permanent bureaucracy designed to implement detention orders. Arguably, had the government consistently done so in reliance on Korematsu, future courts would have had to give some precedential weight to Korematsu.

But this is not what happened. Instead, Korematsu quickly fell into disrepute. ${ }^{139}$ The judgment of history rendered it unreliable,

\footnotetext{
137 This observation reflects only an initial impression. Further analysis might reveal that some kinds of liberty-restricting precedents do in fact induce reliance, and vice versa.

138323 U.S. 214, 217-18 (1944).

139 See Eang L. Ngov, When "The Evil Day" Comes, Will Title VII's Disparate Impact Provision Be Narrowly Tailored To Survive an Equal Protection Clause Challenge?, 60 AM. U. L. REV. 535, 540 \& n.29 (2011) (citing the "universal condemnation of Korematsu").
} 
and other branches of government have indeed not relied on it since. ${ }^{140}$ It has entered the "anticanon" of cases, which has discouraged reliance. ${ }^{141}$ Under these conditions, if the Court were faced with a similar question in the future, it would reasonably discount Korematsu in rendering its decision.

This highlights a startling feature of the reliance approach: a case's precedential status stems not from the fact that the Supreme Court decided it, but rather from the fact that-and only when - other actors rely on the Court's decision. In contrast to the alternative approaches to precedent, this suggests that the Court's analysis of whether to adhere to precedent should focus on the actual effects of the earlier decision and the potential effects of rejecting it.

3. Category 3: Cases in the Middle. The vast majority of cases likely fall somewhere in the middle, in between nonprecedents like Miller, Bowers, Baker, and Korematsu on the one hand and the strongest precedents, such as those that undergird Social Security on the other. These are cases that have generated reliance, but in which the investments and potential losses due to overturning the precedent are of a more limited magnitude. Such cases suggest that the normative force accorded to a precedent is best considered along a spectrum rather than as a binary choice. The greater the reliance interests, the more heavily precedent should weigh on the Court's decision, and vice versa. Here I offer two examples.

Consider the debate over the constitutionality of the individual mandate to purchase health insurance under so-called "Obamacare." ${ }^{142}$ As discussed above, the debate focused a great deal on questions of precedent-to what extent is the individual mandate meaningfully similar to or different from other laws that have been upheld by the Court? ${ }^{143}$ Framed this way, the discourse

\footnotetext{
140 See Harlan Grant Cohen, "Undead" Wartime Cases: Stare Decisis and the Lessons of History, 84 TUL. L. REV. 957, 1013-14 (2010) (explaining how both Congress and the Executive have disapproved of Korematsu).

141 Jamal Greene, The Anticanon, 125 HaRv. L. REv. 379, 380-81 (2011).

142 See Nat'l Fed'n of Indep. Bus. v. Sebelius, 132 S. Ct. 2566 (2012).

143 See supra notes 27-32 and accompanying text. Compare Sebelius, 132 S. Ct. at 2609 (Ginsburg, J., concurring in part, concurring in the judgment in part, and dissenting in part) (citing precedent for constitutionality of mandate), with id. at 2647 (Scalia, Kennedy,
} 
was impoverished by its simplistic and mechanical focus on analogizing and distinguishing cases, without any real substantive focus on why it matters precisely how similar the individual mandate is to previous laws. By approaching the debate with reliance principles in mind, we may substantially refine the analysis.

The critical issue is whether striking down the individual mandate would have frustrated substantial reliance interests and thereby required substantial and costly social reordering. Of course, the Court had never upheld the individual mandate itself in the past, so there was no argument that our current healthinsurance system assumed its constitutionality and would have thus been thrown into chaos. In this narrow sense, then, striking down the individual mandate as unconstitutional would not have been an affront to reliance interests.

From a broader perspective, though, it may have implicated reliance concerns. If the individual mandate is similar enough to other laws that have been upheld by the Court and in which society has invested heavily, then striking down the individual mandate might have introduced substantial doubts as to the continued viability of those laws. Conversely, if the individual mandate can be distinguished in a principled way from these precedents, then they should have had little force. I stress that there must be a principled basis for distinguishing among the cases because in the absence of one, the Court would offer little guidance to the public for future cases and would thus have introduced great instability and uncertainty into the law, thereby interfering with reliance interests. In all likelihood, NFIB $v$. Sebelius implicated reliance interests, but less so than the prototypical case of Social Security.

\section{B. EXPANDING PRECEDENT}

The reliance approach to precedent also demands that we think more broadly about what qualifies as precedent. If the key

Thomas, and Alito, JJ., dissenting) (distinguishing precedent and calling mandate "unprecedented"). 
justification for deferring to precedent is that judges should not impose substantial costs on people for acting based on what they reasonably understand the law to be, then we ought to apply similar constraints on judges whenever people act consistently with a reasonable understanding of the law. In other words, a court should not look simply to its own earlier rulings as sources of precedent. It must also consider other sources upon which people develop reasonable reliance.

1. The Decisions of Sister and Lower Courts. Courts look to the decisions of sister and lower courts as sources of what is referred to as persuasive authority. ${ }^{144}$ There is a great deal of uncertainty concerning the value of this persuasive authority and its justification. ${ }^{145}$ After all, why should a court defer to a court from a different jurisdiction or to one with a lesser degree of authority? ${ }^{146}$

One common response to this question is that such "precedents" do not really have independent normative force, but that the deciding court should carefully consider the substantive arguments contained in them before reaching their conclusions. ${ }^{147}$ The trouble is that this is not an argument for precedential effect because a court should always carefully consider substantive arguments that may have some merit, no matter what their provenance. ${ }^{148}$ There would be little reason to single out or privilege, as we do, the decisions of sister and lower courts as sources of special authority. ${ }^{149}$

I suggest that the concept of persuasive authority is best understood as an implicit acknowledgement or expression of the reliance approach to precedent. The decisions of sister and lower courts have independent normative force when, and to the extent

\footnotetext{
144 E.g., Flanders, supra note 4, at 56.

145 E.g., id. at 56-57; Frederick Schauer, Authority and Authorities, 94 VA. L. REv, 1931, 1940-41 (2008) (questioning whether persuasive authority is actually an oxymoron of sorts).

146 See Flanders, supra note 4, at 56-57.

147 Id. at 65; Schauer, supra note 145, at 1947.

148 Flanders, supra note 4; Schauer, supra note 145, at 1947.

149 See Schauer, supra note 145, at 1947-48 ("[L]ittle would differentiate the genuinely persuasive opinion of a court located in a different jurisdiction from the genuinely persuasive opinion of the judge's father-in-law.").
} 
that, they have generated legitimate reliance interests on the part of the public. ${ }^{150}$ In other words, what determines whether a court should defer to the decisions of sister and lower courts is not whether those courts were correct, but rather what effect they had on the public.

Of course, the decisions of sister and lower courts should not typically wield the same precedential force that a court's own prior opinions do. This is because we internalize the distinctions between courts and consequently do not typically develop strong reliance interests on the basis of decisions of lower courts and the courts of other jurisdictions. That is, we do not usually put as much stock in the decisions of these courts and consequently do not invest as much in the presumption that they will be upheld.

However, there are circumstances in which the decisions of sister and lower courts may well generate substantial reliance, and in these circumstances, they should be accorded precedential weight. For example, if the courts are unanimous or nearunanimous in their opinions concerning a particular issue, if these decisions are longstanding, and if they have become woven into the fabric of a larger body of law, then people may justifiably rely on these decisions. Under these circumstances, such decisions should be considered precedential even among higher courts and courts of other jurisdictions. Indeed, in some cases, the accumulation of such sister- and lower-court decisions over time may carry more weight than a single past decision of the deciding court. After all, as we have already seen, some Supreme Court opinions generate little or no reliance interests, ${ }^{151}$ whereas some decisions by sister and lower courts may give rise to substantial reliance interests. In this sense, the reliance approach implies a sort of flattening of the distinctions between "binding" and "persuasive" precedent. What matters is not which court issued the precedent, but what the ground-level effects of the precedent have been.

This approach may be embedded in, and help to sharpen, a little-noticed argument between Justice Breyer, writing for the

\footnotetext{
150 Cf. Flanders, supra note 4, at 58 (outlining theory of a "hierarchy of persuasive authority").

151 See supra Part IV.A.
} 
majority, and Justice Scalia, concurring, in United States $v$. Tinklenberg. ${ }^{152}$ The Speedy Trial Act generally requires that a trial "shall commence within seventy days" after the arraignment, ${ }^{153}$ but it lists several exclusions from the seventy-day period, including "delay resulting from any pretrial motion, from the filing of the motion through the conclusion of the hearing on, or other prompt disposition of, such motion." 154 The question presented in Tinklenberg was "whether this provision stops the Speedy Trial clock from running automatically upon the filing of a pretrial motion irrespective of whether the motion has any impact on when the trial begins." 155

In an 8-0 opinion, ${ }^{156}$ the Court held that, contrary to the Sixth Circuit, it does. ${ }^{157}$ Justice Breyer's majority opinion begins with a textual and contextual analysis of the statute that favors the government. ${ }^{158}$ He then offers several additional considerations in support of this interpretation. In particular, he states that "we are impressed that during the 37 years since Congress enacted the Speedy Trial Act, every Court of Appeals ... implicitly or explicitly, has rejected the interpretation that the Sixth Circuit adopted in this case." 159 After citing nearly fifteen lower court opinions, Justice Breyer concludes that " $[t]$ his unanimity among the lower courts about the meaning of a statute of great practical administrative importance in the daily working lives of busy trial judges is itself entitled to strong consideration, particularly when those courts have maintained that interpretation consistently over a long period of time."160

In his concurrence, Justice Scalia, joined by Chief Justice Roberts and Justice Thomas, argues that the text of the statute is

152131 S. Ct. 2007 (2011).

${ }_{153}$ Id. at 2010 (quoting the Speedy Trial Act of 1974, 18 U.S.C. $\S 3161(c)(1)$ (2006)) (internal quotation mark omitted).

${ }_{154}$ Id. (quoting 18 U.S.C. $\S 3161(\mathrm{~h})(1)(\mathrm{D})(2006 \&$ Supp. III 2009)) (internal quotation marks omitted).

155 Id. at 2012.

156 Justice Kagan recused herself. Id. at 2010.

157 Id.

${ }_{158}$ Id. at 2012-13.

159 Id. at 2014.

$160 \mathrm{Id}$. 
clear and, therefore, resort to other tools of interpretation is unnecessary. ${ }^{161}$ He takes particular exception to Justice Breyer's argument from the unanimity of the lower courts: "The clarity of the text is doubtless why ... every Circuit disagrees with the Sixth Circuit's conclusion... Clarity of text produces unanimity of Circuits-not, as the Court's opinion would have it, unanimity of Circuits clarifies text."162

Justice Scalia's position is clear enough: what matters is the text, not the lower courts' interpretation of the text. At best, the unanimity of lower courts is evidence as to the text's plain meaning. ${ }^{163}$ In contrast, Justice Breyer's opinion offers no explanation why the unanimity of the lower courts on an issue is ever relevant, or why the fact that the meaning of the statute is "of great practical administrative importance in the daily working lives of busy trial judges" matters. I suggest, however, that he must have had in mind something similar to the reliance approach to precedent. That is, because lower court judges-the group regulated by the statute-have developed practices for handling their dockets on the basis of a unanimous and longstanding interpretation, that interpretation has generated reliance interests.

This is not to say that the reliance approach necessarily leads to Justice Breyer's conclusion. Rather, to evaluate the force of the lower court precedent, it would be necessary to identify what costs would flow from a departure from the lower-court precedents. If the costs are negligible, then Justice Breyer's argument should carry little force. But if the costs are high, then lower-court precedent does provide an independent basis for the Court's holding. Unfortunately, because the Justices seem not to have a

\footnotetext{
161 Id. at 2018 (Scalia, J., concurring in part and concurring in the judgment).

162 Id.

163 Note that even Justice Scalia, the avatar of originalism on the Supreme Court, is sometimes willing to take precedent into account in interpreting statutes due to considerations related to the reliance approach. Hillel Y. Levin, Contemporary Meaning and Expectations in Statutory Interpretation, 2012 U. ILL. L. REV. 1103, 1124. It may be that Justice Scalia is simply unwilling to extend this principle to lower-court precedents.
} 
consistent account of precedent, the Court's consideration of the issue lacks depth. ${ }^{164}$

2. Equitable Estoppel in Administrative Law. Thus far, we have considered the reliance approach only in the context of judicial precedents. However, its animating principles also apply in the administrative context. Administrative agencies and their staffs constantly provide the public with guidance, advice, and authoritative statements. ${ }^{165}$ Such advice ranges from the most informal to the most official. ${ }^{166}$ As with judicial opinions, the public takes such administrative pronouncements seriously as sources of law-and administrative officials and judges would have it no other way. As a result, the public is guided by the advice of administrative officials in deciding how to behave. Such advice should carry some degree of precedential force for the same reasons that judicial opinions do, and it should impose similar constraints on judges. In other words, the statements of administrative officials should sometimes constrain judges and agencies because the public has justifiably relied on those

164 As I have suggested elsewhere, Bell Atlantic Corp. v. Twombly, 550 U.S. 544 (2007), and Ashcroft v. Iqbal, 556 U.S. 662 (2009), together provide another example of the Court implicitly following the lower courts' lead based on reliance principles. Levin, supra note 163, at 1155; Hillel Y. Levin, Iqbal, Twombly, and the Lessons of the Celotex Trilogy, 14 LEWIS \& CLARK L. REV. 143, 149-53 (2010). I suggest there that the Court's application of these principles is less than convincing, perhaps because the Justices have not developed an articulated and coherent framework.

Other cases in which district court opinions may be especially powerful as sources of precedent include those addressing issues that the Supreme Court rarely considers. For example, rules governing discovery practices are primarily the province of district court judges. Some district court opinions have dramatically influenced document-retention practices even among corporations not bound by or subject to the district court. Zubulake $v$. UBS Warburg LLV, 220 F.R.D. 212 (S.D.N.Y. 2003), one of the earliest and most comprehensive district court decisions concerning retention of electronically stored documents is a staple of most civil procedure casebooks, has provided a roadmap for companies around the country. In other words, they have reasonably relied on it because the higher courts are unlikely to provide any more or better guidance. As such, judges should treat it as having precedential effect before imposing costs on those who have conformed their behaviors to it.

165 See Jessica Mantel, Procedural Safeguards for Agency Guidance: A Source of Legitimacy for the Administrative State, 61 ADMIN. L. REV. 343, 348 (2009) ("Agencies employ various means for establishing and implementing federal regulatory policy, including administrative adjudications, informal rulemaking, and guidance documents.").

166 Id. 
pronouncements. The reliance approach thus provides a basis for applying equitable estoppel in the administrative context. Simply put, citizens should be entitled to rely on the advice of their government.

The scholarly literature on this topic is extensive, and some scholars and judges urge the courts to embrace equitable estoppel in the administrative context. Nonetheless, although the Supreme Court has never completely foreclosed the possibility of adopting the doctrine, 167 it has typically rejected its application. ${ }^{168}$ When the Court has been asked to apply equitable estoppel based on the advice of administrative officials, it has declined to do so. It is therefore tempting to conclude that the doctrine does not exist. However, when we look more closely, we find that not to be the case. ${ }^{169}$ Some lower courts have applied the doctrine, and some Supreme Court Justices have embraced it as well.

167 The Court's current doctrine is that there may be some cases in which equitable estoppel is appropriate, but the bar for its application against the government is far higher than in the private context. See Heckler v. Cmty. Health Servs. of Crawford Cnty., Inc., 467 U.S. 51, 60-61 (1984) ("[I]t is well-settled that the Government may not be estopped on the same terms as any other litigant. [The Government] urges us to expand this principle into a flat rule that estoppel may not in any circumstances run against the Government. We have left the issue open in the past, and do so again today. Though the arguments the Government advances for the rule are substantial, we are hesitant, when it is unnecessary to decide this case, to say that there are no cases in which the public interest in ensuring that the Government can enforce the law free from estoppel might be outweighed by the countervailing interest of citizens in some minimum standard of decency, honor, and reliability in their dealings with their Government." (footnote omitted)).

168 E.g., Office of Pers. Mgmt. v. Richmond, 496 U.S. 414, 434 (1990); Schweiker v. Hansen, 450 U.S. 785, 789-91 (1981); Fed. Crop Ins. Corp. v. Merrill, 332 U.S. 380, 383-86 (1947).

169 Although the Court does not appear to have ever explicitly accepted an argument based on equitable estoppel against the government, it does appear to have implicitly adopted some version of the doctrine or its animating principles. For example, in Moser v. United States, 341 U.S. 41 (1.951), although the Court disclaimed equitable estoppel as the basis for its opinion against the government, $i d$. at 47 , many commentators interpret the opinion as expressing some form of equitable estoppel, e.g., 4 CHARLES H. KOCH, JR., ADMINISTRATIVE LAW AND PRACTICE § 12:36 (3d ed. 2010). Likewise, in Kaiser Aetna v. United States, although the Court held that the government was not estopped based on agency advice, the party that sought the agency's advice was nevertheless entitled to partial relief based on its justifiable reliance on that advice. 444 U.S. 164, $179-80$ (1979); see also United States v. Indus. Pa. Chem. Corp., 411 U.S. 655, 674 (1973) (applying due process in a manner similar to equitable estoppel to prevent the government from imposing criminal liability against a defendant who had been assured by the agency that its conduct was lawful). 
A leading case in which a lower federal court applied equitable estoppel against the government is Alaska Professional Hunters $v$. $F A A,{ }^{170}$ which concerned Alaskan hunting and fishing guides who pilot light aircraft as part of their services. The D.C. Circuit considered whether an agency's longstanding informal, oral advice to the guides could be overturned by the agency's announcement that it would no longer follow that policy. ${ }^{171}$ The court held that the agency could not simply adopt a new policy because its prior informal guidance had been given and adhered to consistently over time by the agency, and because the regulated community had justifiably relied on and invested resources on the basis of the advice. ${ }^{172}$ Instead, if the agency wanted to change its enforcement policies, it would have to promulgate an official regulation. ${ }^{173}$ In other words, the agency's advice constituted a sort of precedent that bound the agency and court. As the court put it, "[t]hose regulated by an administrative agency are entitled to "know the rules by which the game will be played.' [The guidees] relied on the advice FAA officials imparted to them [and organized their affairs accordingly]."174 Therefore, the only way to change the policy was for the agency to engage in a rulemaking process that would provide those affected by the rule an opportunity to make their case and that could yield a policy mitigating the costs that would be incurred by those who had relied on the earlier policy.

The Ninth Circuit also applied equitable estoppel against the government in Watkins $v$. United States Army. ${ }^{175}$ In that case, the U.S. Army had refused to reenlist the plaintiff on the grounds that he was homosexual. ${ }^{176}$ The applicable rules suggested that homosexuals would be excluded from the military. ${ }^{177}$ However, the Army had previously permitted Watkins to reenlist despite its

\footnotetext{
170177 F.3d 1030 (D.C. Cir. 1999).

171 Id.

172 Id at $1035-36$

173 Id.

174 Id. at 1035 (citation omitted).

175875 F.2d 699 (9th Cir. 1989).

176 Id. at $702-03$.

177 Id.
} 
knowledge of his homosexuality. ${ }^{178}$ Consequently, he invested heavily in his career. The court applied equitable estoppel and required the Army to allow him to reenlist. ${ }^{179}$ Likewise, in Griffin $v$. Reich, a district court held that the government's representations concerning wage requirements in the context of a government contract could give rise to equitable estoppel. ${ }^{180}$

Further, some Supreme Court Justices have expressed support for equitable estoppel. In United States $v$. Locke, Justice O'Connor argued in a concurrence that an agency's advice that paperwork could be filed with the agency through December 31 may estop the government from applying the plain language of the statute, which provided that the paperwork must be filed "prior to December 31."181 Likewise, Justice Powell argued in dissent that due process-animated by similar principles-prevented the government from applying the plain language of the statute. ${ }^{182}$

What all of this demonstrates is that the principles that animate the reliance approach to judicial precedent also operatealbeit in considerably muted and weakened form-in the context of administrative agencies. In effect, judges sometimes feel compelled to treat some kinds of agency behaviors and pronouncements as having precedential force. Simultaneously, however, the reliance approach suggests that the courts ought to embrace estoppel more than they do, and the failure of the courts to forthrightly express these principles has cramped their application. ${ }^{183}$

\footnotetext{
$178 I d$, at 702.

$179 I d$. at 711. Lower federal courts have also adopted some form of equitable estoppel. Amanullah v. Cobb, 862 F.2d 362, 367 (1st Cir. 1988); cf. United States v. Argo, 925 F.2d 1133, 1135 (9th Cir. 1991) (Tang, J., dissenting). But see Yerger v. Robertson, 981 F.2d 460, 466 (9th Cir. 1992); Ingalls Shipbuilding. Inc. v. OWCP, 976 F.2d 934, 937-38 (5th Cir. 1992). State courts also sometimes apply equitable estoppel against the government. E.g., Appeal of Eno, 495 A.2d 1277, 1281-82 (N.H. 1985).

180956 F. Supp. 98, 109-10 (D.R.I. 1997).

181471 U.S. 84, 111 (1985) (O'Connor, J., concurring).

182 Id. at 112 (Powell, J., dissenting).

${ }^{183}$ It is noteworthy that European and British law are more explicit about the role of equitable estoppel and legitimate expectations in administrative law. See ROBERT THOMAS, LEGITIMATE EXPECTATIONS AND PROPORTIONALITY IN ADMINISTRATIVE LAW 44-57 (2000) (comparing European and British approaches to reliance interests in administrative law).
} 
3. Public Discourse and Practice. The final and potentially most controversial extension of precedential status under the reliance approach is to the discourse and practices of the public. In some circumstances, people reasonably look to social cues to understand what the law requires of them. Indeed, given the broad reach and complexity of the law, it would be unrealistic, and therefore unfair, to expect otherwise. Thus, based on social practices, people may develop reliance interests that courts should be wary of undermining.

The principal difficulty in extending precedent to social discourse and practice is that it is difficult to precisely identify the point at which public understanding gains sufficient legitimacy to constrain courts. I consider this challenge at length later, ${ }^{184}$ but for present purposes I suggest that the hallmarks for courts ought to be: first, whether the behavior or understanding is widespread, and second, whether legal authorities are aware of the practice and have given implied or actual consent to it. To be sure, this leaves much gray area, and reasonable minds will differ in specific cases as to whether reliance is legitimate. But, once again, this approach at least provides guidance to courts as to what questions to ask. Unfortunately, judges rarely ask such questions.

I offer three brief case studies to illustrate how the development of reliance interests based on social behavior and discourse may operate as a form of precedent. In the first two examples, the courts did not explicitly consider reliance interests, but the opinions would have benefited from such an analysis and are best understood and defended through the reliance lens. By contrast, in the third case, the court was unusually explicit in its consideration of these principles.

a. In re Rachel L. ${ }^{185}$ One example of a court implicitly applying the reliance approach is a California appellate court case concerning the legality of homeschools. ${ }^{186}$ With limited exceptions, the governing statute appeared to prohibit parents from

\footnotetext{
184 See infra Part V.B.

185 In re Rachel L., 73 Cal. Rptr. 3d 77 (Cal. Ct. App. 2008), abrogated by Jonathan L. v. Superior Court, 81 Cal. Rptr. 3d 571 (Cal. Ct. App. 2008).

186 Id.
} 
homeschooling their children. ${ }^{187}$ In a straightforward application of the rules of statutory interpretation, the court initially held that most homeschooling was unlawful under the statute. ${ }^{188}$ Upon reconsideration, however, the court reversed course and held that the statute permits homeschooling as a statutorily permitted form of private schooling. ${ }^{189}$ To reach this conclusion, the court stretched the rules of statutory interpretation beyond plausibility. ${ }^{190}$

A better justification for upholding homeschooling under the statute would have been for the court to forthrightly acknowledge that as many as 250,000 children are homeschooled each year; that the children's parents made the choice to homeschool with the full knowledge and tacit encouragement of California's administrative and legislative authorities and therefore developed a legitimate belief that their actions were lawful; and that the sudden declaration that homeschooling is unlawful would have had unpredictable effects and imposed numerous uncertainties and costs on affected families and the public school system. ${ }^{191}$

In other words, the court would have been better off had it transparently reasoned that, for the very same reason that courts should not overturn their own precedents, it should uphold the public understanding and practice concerning homeschooling. This would have been a more honest and persuasive defense of its holding than the court's interpretive contortions. Thus, the court's intuition and impulse may have been correct, but the absence of explicit doctrine concerning the normative force of reliance interests deprived the court of the best vocabulary for addressing the issue.

b. Sherley v. Sebelius. ${ }^{192}$ Another case that would have benefited from a reliance analysis is Sherley $v$. Sebelius, in which the plaintiffs challenged government funding of human embryonic

\footnotetext{
187 I have discussed this case extensively elsewhere. Levin, supra note 163, at 1144-49.

188 Rachel L., 73 Cal. Rptr. 3d at 84.

189 Jonathan L., 81 Cal. Rptr. 3d at 589-90.

190 See Levin, supra note 163 , at 1145-47.

191 Id. at $1148-49$.

192644 F.3d 388 (D.C. Cir. 2011).
} 
stem cell research based on a 1996 statute that prohibited such funding for "research in which a human embryo or embryos are destroyed."193 The question presented by the case was whether this statute prohibited funding of research on embryonic stem cells where the destruction of the human embryo was undertaken with only private funding. ${ }^{194}$ That is, the NIH did not fund the destruction of the embryos necessary to the extraction of its stem cells, but it did fund subsequent research using the stem cells or "lines" derived from them.

Sherley presents a fascinating set of statutory interpretation questions. Cheuron deference, plain meaning, legislative history, congressional intent, and purposivist arguments abound in the briefs and judicial opinions. ${ }^{195}$ An opinion tally suggests that the case is a close one: the district judge and one judge on the court of appeals sided with the plaintiffs, holding that the plain language of the act prohibited funding of such research, while the two-judge court of appeals majority reached the opposite conclusion. However, if the courts had viewed the case through a reliance lens, its outcome would have been clearer.

At the time the statute was enacted in 1996,196 the policy challenged in Sherley was not addressed because technology had not yet been developed that allowed for the extraction of human embryonic stem cells. 197 In 1999, under President Clinton, the Executive Branch adopted the position that human embryonic stem cell research would be federally funded if the stem cells were

\footnotetext{
193 Id. at 390.

194 Id at 391.

195 For example, the appellants argued that "[w]hen Congress reenacted the DickeyWicker amendment after President Bush's announcement of his policy, the relevant Committees made clear that the legislative language did not impose a ban on research using embryonic stem cells" and also appealed to Chevron deference in arguing that the district court had failed to accord proper deference to "NIH's consistent and longstanding interpretation of the statute." Brief for Appellants at 12, 19, Sherley, 644 F.3d 388 (No. 10 5287). The appellees claimed that the plain meaning of the statute supported their interpretation of it, arguing that the statute was unambiguous. Brief for Appellees at 1419, Sherley, No. 644 F.3d 388 (No. 10-5287). The court concluded that the statute was ambiguous and thus Chevron deference should apply. Sherley, 644 F.3d at 394.

196 Pub. L. No. 111-117, § 509(a)(2), 123 Stat. 3034, 3280-81 (2009).

197 Sherley, 644 F.3d at 390.
} 
procured from a process in which the human embryo was not destroyed using federal funds. ${ }^{198}$ Thus, the Administration introduced the position subsequently defended in Sherley.

In 2001, President Bush's Administration adopted a different policy. ${ }^{199}$ The government would no longer fund research involving new human embryonic stem cells and "lines."200 However, the government would continue to fund research involving human embryonic stem cell lines that had been created by privately funded researchers before the adoption of the new policy. ${ }^{201}$ Thus, the Bush Administration agreed that the statute permitted federal funding for research that required the destruction of human embryos, so long as the destruction itself was privately funded. Finally, in 2009, President Obama's Administration adopted a new set of regulations that essentially restored the Clinton Administration's policy. ${ }^{202}$

At no point during these ten years did Congress intervene to ban funding for all research on human embryonic stem cells that required the destruction of human embryos. In fact, in the years after the Bush Administration announced its policy, Congress passed multiple bills that would have eased such restrictions and at least reintroduced the Clinton-era approach. ${ }^{203}$ During the congressional debates, opponents of these new bills never suggested that both the Clinton and Bush policies violated the 1996 law or that the new legislation would overturn it. Thus, both branches of government consistently signaled support for what became the Sherley defendants' position. It was therefore reasonable for medical researchers to conclude that federal funding would be available for at least some human embryonic stem cell research and to develop substantial and legitimate

198 Id. at $390-91$.

$199 \mathrm{Id}$.

$200 \mathrm{Id}$.

201 Brief for Appellants, supra note 195, at 12.

202 Id. at 13.

${ }^{203}$ E.g., Stem Cell Research Enhancement Act of 2005, H.R. 810, 109th Cong. $\S 498 D(b)$ (2005). President Bush vetoed this bill. Library of Cong., Bill Summary \& Status-109th Congress (2005-2006)-H.R. 810-All Information, http://thomas.loc.gov/cgi-bin/bdquery/z?d10 9:HR00810:@@@\&summZ=ml (last visited Apr. 20, 2013). 
reliance interests as a result. Unfortunately, most of this history is absent from the opinion.

Also missing from the opinion is any sense of what the real stakes in the case were. In the years 2002-2011, the NIH issued more than $\$ 650$ million in grants for human embryonic stem cell research. ${ }^{204}$ Scientists organized their laboratories and focused their research based on the availability of such funding, and students surely relied on it in developing their expertise and research agendas. In other words, the reasonable public understanding that funding for such research was lawful and available led people to organize their lives and invest their resources in reliance. For the court to rule to the contrary would greatly disrupt the lives and professions of those who reasonably relied on longstanding and widespread practices that enjoyed the longstanding support of both parties in government. While the costs imposed by such a ruling would hardly rise to the level of a Supreme Court declaration that the Social Security system is unconstitutional, it should count for something-and perhaps be dispositive in an otherwise close case.

The appellate court's holding in the case is, in the end, consistent with the reliance approach. However, its decision to ignore all of the facts related to reliance interests and instead to focus exclusively on doctrines of statutory interpretation is unfortunate, even as it reflects the typical practice among courts. It impoverishes the analysis because it treats the law as entirely removed from human experience and the moral implications inherent in confounding public understanding of the law. It also makes the case much more difficult than it needs to be.

c. United States v. Nosal. ${ }^{205}$ In contrast to Rachel L. and Sherley, the Ninth Circuit's recent en banc decision in United States $v$. Nosal offers an unusually candid application of the reliance approach. The question in Nosal was whether individuals who violate employer computer policies or the terms of service of social-networking sites are potentially criminally liable under the

204 See NIH Stem Cell Research Funding, FY 2002-2012, NAT'L INST. FOR HEALTH, http:// stemcells.nih.gov/research/funding/pages/Funding.aspx (last visited Apr. 20, 2013).

205676 F.3d 854 (9th Cir. 2012). 
Computer Fraud and Abuse Act (CFAA). ${ }^{206}$ Under the CFAA, a person is liable if he or she "access[es] a computer without authorization and...use[s] such access to obtain or alter information in the computer that the accesser is not entitled so to obtain or alter."207 In prosecuting Nosal, the government argued that this provision criminalizes accessing an employer's computer in a way that violates the employer's computer policies. The defendant argued that the provision only targets a particular form of hacking, namely where someone is "authorized to access only certain data or files but accesses unauthorized data or files." 208

The majority's analysis applies many of the standard tools one would expect to see in a case presenting a statutory interpretation question: plain meaning, ${ }^{209}$ the whole act rule, ${ }^{210}$ the rule of interpreting statutes consistently with preexisting common law, ${ }^{211}$ and legislative history and purpose. ${ }^{212}$ But the bulk of the opinion focuses on the fact that, as the majority puts it, "[w]ere we to adopt the government's proposed interpretation, millions of unsuspecting individuals would find that they are engaging in criminal conduct." 213 Substantively, this is a reliance argument, and it convinced the majority to reject the approach of all of the other federal appellate courts to have considered the issue ${ }^{214}$ and to adopt what the dissent refers to as an interpretation that "distorts the obvious intent of Congress" and the "perfectly clear" meaning of the statute. ${ }^{215}$

\footnotetext{
206 Id. at 856.

20718 U.S.C. $\S 1030(\mathrm{e})(6)(2006)$.

${ }_{208}$ Nosal, 676 F.3d at 856-57.

209 Id. at 863 . The plain meaning rule "prohibits consideration of nontextual sources in the absence of statutory ambiguity." Abbe R. Gluck, The States as Laboratories of Statutory Interpretation: Methodological Consensus and the New Modified Textualism, 119 YALE L.J. $1750,1755(2010)$.

${ }^{210}$ Nosal, 676 F.3d at 859 . This rule calls for the interpreter to consider the textual context of the rest of the statute. Gluck, supra note 209 , at $1763 \&$ n. 37 .

${ }^{211}$ Nosal, 676 F.3d at 857; Gluck, supra note 209, at 1825.

${ }_{212}$ Nosal, 676 F.3d at 858; Gluck, supra note 209, at 1763.

213 Nosal, 676 F.3d at 859.

214 Id. at 862.

${ }^{215} I d$. at 864 (Silverman, J., dissenting).
} 
Chief among the majority's concerns was that under the government's reading of the statute, anyone who uses an employer's computer in a way that violates the employer's policies-for example, by playing games, surfing the web, or conducting personal business-or who uses a social-networking site in a manner that violates the site's terms of service is engaged in criminal conduct. ${ }^{216}$ The opinion discusses at great length the public's reasonable expectation and understanding to the contrary. ${ }^{217}$ For example, the court states that the public "ha[s] little reason to suspect that they are committing a federal crime" when they engage in such activities; ${ }^{218}$ that personal use of work computers is a routine and general public practice; ${ }^{219}$ that employer-employee relationships are usually governed by tort and contract rather than criminal law; ${ }^{220}$ that criminal liability would turn on employee agreements that the public would have difficulty interpreting; ${ }^{221}$ that the public cannot be expected to understand and abide by all of the terms-of-service agreements imposed by websites; ${ }^{222}$ that the government's interpretation would turn unsuspecting children who use websites that prohibit use by minors into "juvenile delinquents," and their parents into "delinquency contributors"; 223 and that criminal liability could change at any moment, since websites retain the right to change their terms of service without notice. ${ }^{224}$

\footnotetext{
216 Id. at 860 (majority opinion) ("Basing criminal liability on violations of private computer use policies can transform whole categories of otherwise innocuous behavior into federal crimes simply because a computer is involved.").

217 I am tempted to quote the entirety of the court's lengthy and colorful discussion because it so beautifully makes the point, but the journal-editor overlords typically (and correctly) do not look kindly on multipage block quotes. Therefore, I encourage readers to simply read the relevant portion of the opinion. See id. at 859-62.

218 Id. at 859.

${ }_{219} I d$. at 860 ("Minds have wandered since the beginning of time and the computer gives employees new ways to procrastinate. ...").

220 Id.

${ }^{221}$ Id. ("Significant notice problems arise if we allow criminal liability to turn on the vagaries of private policies that are lengthy, opaque, subject to change and seldom read.").

$222 \mathrm{Id}$. at 861.

223 Id.

${ }_{224} I d$. at 862 .
} 
All of these arguments evidence the court's profound discomfort with interpreting a criminal statute to conflict with broad and legitimate public understanding and behaviors in a way that may lead to arbitrary, malicious, and discriminatory enforcement. ${ }^{225}$ To be sure, the court ultimately uses these arguments as a basis for applying the familiar rule of lenity. ${ }^{226}$ But as I have argued elsewhere, the rule of lenity is best understood as an expression of reliance principles. 227 Indeed, all of the formal tools of interpretation that the court references in favor of its conclusion resonate with the reliance approach in this context. For example, the court references the doctrine that ambiguous statutes are to be construed consistently with the common law. ${ }^{228}$ The best explanation for this rule, at least in this context, is that it imposes a kind of stability on the law and protects the justified expectation of the public that longstanding law would not be overturned without explicit consideration by the legislature. The same is true of the court's references to the statute's purpose and legislative history; the court notes that Congress's focus and intent was to respond to the problem of hacking rather than computer use that violates employer and website policies. ${ }^{229}$ Likewise, the court argues from the broader legal structure that the kinds of behavior targeted by the prosecution in this case are the subject of different statutes and areas of the law, and it would be unlikely for Congress to have addressed this behavior in a hacking statute. ${ }^{230}$

All of this suggests that the reliance approach, even in its most radical manifestations, is embedded deeply in legal doctrine. Unfortunately, it is embedded so deeply that it is typically overlooked; Nosal's frankness is the exception rather than the rule.

\footnotetext{
$225 I d$. at 860 ("Ubiquitous, seldom-prosecuted crimes invite arbitrary and discriminatory enforcement.").

226 Id. at 863.

227 See Levin, supra note 163, at 1128 ("The rule of lenity is justified by the principle that a law can only have force if the regulated community can reasonably understand the law."); see also Nosal, 676 F.3d at 863.

228 Nosal, 676 F.3d at 857.

229 Id. at 858.

230 Id. at 860 .
} 


\section{OBJECTTONS AND REFINEMENTS}

Given its far-reaching implications and the revisionary account it offers for precedent, the reliance approach inevitably invites challenges. In this Part, I identify two potential objections to the approach and, in addressing them, consider some possible refinements that deepen our understanding of its operation. I also suggest that our formalist discourse concerning precedent has developed to tacitly acknowledge reliance interests but simultaneously blunt its force in response to some of the problems it raises.

\section{A. THE EVIL PRECEDENT PROBLEM}

One potential objection to the reliance theory of precedent is that it may require courts to uphold undesirable precedents. This objection is best illustrated by the case of Brown $v$. Board of Education, ${ }^{231}$ which, as every law student knows, effectively overturned the longstanding precedent of Plessy $v$. Ferguson. ${ }^{232}$ One could argue that Plessy generated substantial reliance on the part of the public, and that Brown imposed precisely the kinds of costs associated with reordering society that the doctrine of precedent is meant to protect against. In other words, if this approach to precedent is correct, then wasn't the Brown court wrong to overturn Plessy?

Note first that any theory of precedent must grapple with this problem. That is, anyone who believes that precedent should carry normative force-which is to say, nearly everyone ${ }^{233}$-must account for Brown. Arguably, the reliance approach fares better in this regard than other approaches because of the ways in which it limits precedential force. ${ }^{234}$ Thus, there may be any number of evil precedents that courts could readily ignore simply because those

\footnotetext{
231347 U.S. 483 (1954).

${ }^{232}$ Id. at 494-95, overruling Plessy v. Ferguson, 163 U.S. 537 (1896).

${ }^{233}$ One notable exception is Lawson, supra note 1, at 24 (arguing that "the practice of following precedent . . . is affirmatively inconsistent with the federal Constitution").

234 See supra Part IV.A.
} 
precedents do not implicate the reliance principles, ${ }^{235}$ and there are other cases that have given rise to fairly limited reliance interests, in which case precedent would weigh less heavily. ${ }^{236}$ This point does not help us in the specific case of Plessy, around which large segments of society did in fact organize themselves, but as a general matter, the reliance approach has less to answer for with respect to this problem than do other approaches.

One response to the evil precedent problem is that precedent is but one factor for judges to consider, and it must be weighed against other countervailing factors and the costs associated with upholding precedent. In particular, because the reliance approach maintains that the power of precedent is based on a moral principle, ${ }^{237}$ it may be outweighed where a judge believes that the precedent was wrongly decided and that there are stronger moral considerations on the other side. Thus, if the Justices concluded that practice had shown that Plessy's separate-but-equal rationale violated equal protection, then the moral dimension to the Equal Protection Clause - that people should not receive worse treatment by the law simply on account of their skin color-offers a basis for rejecting precedent.

In broader terms, this means that adherence to even the strongest precedents is not an absolute command. While this may be unsatisfactory to some because it disclaims hard-and-fast rules that could be readily applied in every case, the truth is that the nature of judging is that it requires judgment. If we deem multifactor tests in which judges must balance competing interests unacceptable, then we ought to shut down our courts. After all, such tests and the disagreements they produce are present and tolerated throughout our legal order. What the reliance approach to precedent accomplishes is that it offers a common basis for analyzing certain legal questions, thereby channeling and focusing discourse and disagreement. Judges may continue to disagree in some cases, but they will disagree on common terms.

\footnotetext{
235 See supra Part IV.A.1.

236 See supra Part IV.A.2.

237 See supra Part III.C.
} 
A further response to the Plessy problem is that it may be a mistake to view Brown's rejection of Plessy as undermining the public's reasonable reliance interests. Indeed, the reliance approach to precedent may be consistent with Brown. Consider Brown in its larger context, for it was not decided in a vacuum, and it did not suddenly and unexpectedly overturn Plessy. Rather, Brown was the inevitable culmination of a long series of legal and social developments. ${ }^{238}$ Advocates for equality did not push the socially fraught issue of constitutionally mandated school integration to the Supreme Court at the beginning of their assault on segregation laws. ${ }^{239}$ Instead, they advanced such cases at the state, local, and district court level, while simultaneously bringing less contentious challenges to segregation to the Supreme Court. ${ }^{240}$ Over time, a strong trend and principle of integration emerged from these cases, laying the groundwork for Brown. By the time Brown was brought, attitudes toward segregation had substantially shifted; the majority of the country viewed segregated schools as an affront to equality. ${ }^{241}$ In other words, the public understanding had disintegrated, and there was no longer any general and reasonable reliance belief that Plessy would remain in place.

In this way, advocates and the courts adopted an incrementalist reshaping of precedent and public understanding that the reliance

238 See Michael J. Klarman, Brown, Racial Change, and the Civil Rights Movement, 80 VA. L. REV. 7, 10 (1994) (arguing that "racial change in America was inevitable owing to a variety of deep-seated social, political, and economic forces" and "the Brown decision was judicially conceivable in 1954 only because the forces for change had been preparing the ground for decades").

${ }^{239}$ For an in-depth account of such advocates' long-term approach to litigation, see MARK

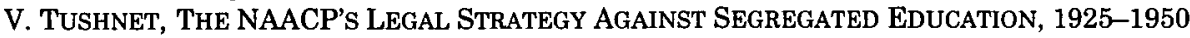
(1987).

240 See, e.g., Sweatt v. Painter, 339 U.S. 629 (1950) (holding unconstitutional the University of Texas Law School's denial of admission to blacks because the proposed law school for blacks was not substantially equal); Missouri ex rel. Gaines v. Canada, 305 U.S. 337 (1938) (holding Missouri could not deny admission to its law school to blacks because there was no separate in-state law school for blacks).

241 A Gallup poll taken shortly after Brown was handed down found that $54 \%$ of people agreed with the Court's decision. Jack Ludwig, Race and Education: The 50th Anniversary of Brown v. Board of Education, GALLUP NEwS SERV., Apr. 27, 2004, http://www.gallup.com/ poll/11521/race-education-50th-anniversary-brown-board-education.aspx. 
theory permits and encourages. Indeed, by the time Brown was decided, no one-not even those who decried it-could have reasonably claimed to be surprised by the Court's ruling. To be sure, there was opposition to Brown, and Brown required opponents to make changes in their lives that they did not like and that may have cost them whatever investment they had in Plessy. But this was more due to a strong disagreement with the principle of integration than to a fair expectation on the basis of Plessy that segregated schools would forever remain available.

What makes this account especially compelling is that the Court itself seems to have been cognizant of the potential for social upheaval that Brown might engender. It is likely for this very reason that the Court included the fateful words "with all deliberate speed" in its order. ${ }^{242}$ The Justices were apparently bothered by the potential costs that could arise due to their rejection of precedent, and the "deliberate speed" language was intended to give states and schools the time and latitude to develop and implement plans for the integration of the schools.

One troubling implication of understanding Brown in this manner is that it suggests that the Court would have been on shakier ground had it decided a case like Brown before the groundwork had been laid. That is, if Brown is seen as consistent with the reliance approach to precedent, then perhaps the Court would have been morally compelled to uphold Plessy before 1954, and the reliance approach might still require courts to uphold evil precedent in some cases. As difficult as this may be to accept-we all wish for courts to achieve just results in all cases-we should ultimately acknowledge that any neutral jurisprudential theory will have to tolerate bad results in some cases. The benefit of the reliance approach is that it offers an avenue for the pivot away from precedent and for incremental progress toward legal change.

A correlated benefit of this relative judicial conservatism is that it requires greater social and political engagement on the part of advocates for legal change. They cannot assume that the courts will solve their problems for them with a stroke of the pen, and

242 Brown v. Bd. of Educ., 349 U.S. 294, 301 (1955). 
they must therefore work on multiple fronts simultaneouslyshaping public opinion, advocating before the political branches, working in the states, and moving incrementally in the courts-in order to achieve significant social and legal change. Such efforts are far more likely to produce meaningful and lasting change than a single Supreme Court opinion ever could. Although it may come at a cost of tolerating some evil precedents like Plessy for longer than we would like, the reliance approach fosters more substantial civic engagement and is thus more consistent with democratic principles than is unpredictable judicial action. In this sense, the majoritarian-affirming tendency of the approach may be at least as much of a feature as it is a bug. ${ }^{243}$

243 Intriguingly, this reliance approach to Brown gives a normative justification for what we typically think of as lawyers' strategic calculations. Activists for social and legal change on issues like recognition of same-sex marriage, limiting abortion rights, and death-penalty reform have turned to the courts in the hopes that they will achieve quick and far-reaching victories, but they have been disappointed in each case. These disappointments have led advocates to implement incrementalist strategies to achieve their desired reforms rather than relying on the Supreme Court.

For example, same-sex marriage advocates have slowly developed a favorable body of law by making public arguments for their cause, seeking victories in state legislatures, litigating in carefully chosen state courts, bringing more limited lawsuits in the federal courts (including challenges to anti-sodomy laws and the Defense of Marriage Act), and seeking more limited forms of recognition for same-sex relationships. See, e.g., Lawrence v. Texas, 539 U.S. 558 (2003); Romer v. Evans, 517 U.S. 620 (1996); Windsor v. United States, 699 F.3d 169 (1st Cir. 2012), cert. granted, 133 S. Ct. 786 (2012); In re Golinski, 587 F.3d 901 (9th Cir. 2009) (reversing denial of health benefits to homosexual); Collins v. Brewer, 727 F. Supp. 2d 797 (D. Ariz. 2010) (granting preliminary injunction against denial of health-care coverage to homosexuals). Advocates for same-sex marriage now seek complete relief in the federal courts, but only after they built substantial public support and amassed favorable precedents. See Hollingsworth v. Perry, $133 \mathrm{~S}$. Ct. 786 (2012), granting cert., Perry v. Brown, 671 F.3d 1052 (9th Cir. 2012).

Similar stories can be told about conservative efforts to prohibit or limit abortion rights and liberal efforts to abolish the death penalty. Abortion opponents were disappointed both by Roe's refusal to grant fetuses constitutional protection and by its grant of expansive, constitutionally guaranteed abortion rights. Roe v. Wade, 410 U.S. 113, 158, 165-66 (1973). They were again disappointed when the Court in Casey dashed their hopes by upholding the core of Roe. See Planned Parenthood of Se. Pa. v. Casey, 505 U.S. 833, 869-79 (1992). Since then, conservatives have had remarkable success in slowly eroding the Roe framework and limiting access to abortion with state legislative victories and by successfully defending incremental restrictions in the federal courts. See, e.g., Gonzales v. Carhart, 550 U.S. 124 (2007) (upholding ban on partial-birth abortions); Tex. Med. Providers Performing Abortion Servs. v. Lakey, 667 F.3d 570 (5th Cir. 2012) (upholding laws requiring physicians to disclose sonogram and fetal heartbeat before performing an abortion); O'Brien v. Mayor \& 


\section{B. THE TIPPING POINT PROBLEM}

The second problem with the reliance approach is what I call the tipping point problem. Succinctly stated, the tipping point problem is that if the key to precedent lies in public reliance, then it may be difficult for judges to assess whether enough reliance interests have legitimately arisen such that they ought to be protected. This challenge may be broken down into a series of related questions about the approach: How much public reliance is enough to create a precedent that should be adhered to? When is such reliance reasonable? When has there been sufficient incremental roll-back to reject earlier precedents? And finally, why would we believe that judges are at all qualified to make judgments about public reliance?

As observed above, ${ }^{244}$ the judicial enterprise implies the application of judgment. There may be no hard-and-fast rules for applying the approach, but judges must balance competing interests and make judgment calls in a wide variety of contexts. The reliance approach simply requires them to make different ones. $^{245}$ At the very least, we would know what the terms of the

City Council of Balt., 768 F. Supp. 2d 804 (D. Md. 2011) (striking down a city ordinance requiring providers of pregnancy-related services to post a conspicuous sign in their waiting rooms concerning the availability of abortion).

Likewise, when death penalty opponents failed in their attempts to ban the practice in the Supreme Court, Gregg v. Georgia, 428 U.S. 523 (1976), they achieved some success by turning to incrementalist strategies in the states and federal courts, see, e.g., Roper v. Simmons, 543 U.S. 551 (2005) (eliminating death penalty for those under the age of eighteen); Ford v. Wainwright, 477 U.S. 399 (1986) (eliminating death penalty for insane persons); Coker v. Georgia, 433 U.S. 584 (1977) (eliminating death penalty for rape of adults). Eventually, if advocates for these causes continue to be successful in their incremental efforts and win public support, and if the Supreme Court appears favorably disposed, they will use these smaller victories as building blocks for a much broader legal assault-and the incremental developments will give the courts a framework and justification for revisiting their earlier decisions.

Typically, this account of legal change is offered as merely descriptive. That is, it explains how savvy lawyers strategize to achieve their results. But, viewed through the lens of the reliance approach, it provides a normative account as well, explaining why this approach can work, and indeed why-putting aside the underlying substantive arguments in each case-it should.

244 See supra Part V.A.

245 With respect to the question of what constitutes "reasonable" reliance, I note that reasonableness is an especially common standard in the law, and "reasonable reliance" is 
debate over precedent are, which is a vast improvement over the status quo, in which everyone argues about precedent but no one articulates why. Judges and advocates would have to refocus their arguments and inquiries to clearly articulate what they believe the public understands, on what basis, and what the effects of disturbing that understanding would be. The connection between legal doctrine and ground-level practices would be openly explored and would represent a primary focal point for judicial inquiry.

To be sure, this response may be incomplete because the types of judgments that judges would be required to make in applying this approach to precedent may be different in kind from the types of judgments they must make in other circumstances. Requiring judges to identify what the public understands about the law and the circumstances that gave rise to that understanding as well as to predict what the effects of their ruling on people's reliance interests will be, is meaningfully different from requiring them to interpret texts, articulate and apply legal principles, and analogize and distinguish facts. Judges are trained and have a claim to expertise with respect to the latter, but perhaps not the former.

One response is that simple judicial acknowledgement of the role of reliance would aid us in identifying proxies and heuristics that judges may use. Judges would consider, for example, the number of times a precedent has been upheld, how often lower courts cite to it, whether there is disagreement among courts that have considered the matter, how connected it is with the larger fabric of the law, how carefully past courts considered the issue, the size of the majority that created the precedent, how many people would be subject to legal consequences if the court rejects the precedent, and so on. ${ }^{246}$ Indeed, such considerations are already present in the law. If nothing else, the reliance approach

also an element in other areas of the law. I see little reason why this question is more problematic in this context.

${ }_{246}$ See Levin, supra note 163, at 1140-44 (outlining factors for public reliance); see also Randy J. Kozel, Stare Decisis as Judicial Doctrine, 67 WASH. \& LEE L. REV. 411, 452-64 (2010) (noting that "[d]eveloping a framework to analyze reliance interests requires identifying the discrete ways in which reliance on a precedent can manifest itself" and examining some such ways); John O. McGinnis \& Michael B. Rappaport, Reconciling Originalism and Precedent, 103 NW. U. L. REV. 803, 844 (2009) (noting factors for reliance). 
provides a coherent account for why ${ }^{247}$ once again demonstrating the descriptive power of the approach.

There is a related way to address the tipping point problem. At first glance, there appears to be considerable tension between the doctrinal language used to discuss precedent and the reliance account. On the one hand, the doctrinal discourse is dominated by formal categorization. We have binding precedent, persuasive precedent, dicta, and so forth. These categories imply mechanical distinctions concerning the power of different kinds of precedent. For example, if a case qualifies as super-precedent, it may never be overturned, whereas if it is merely dicta or persuasive precedent, it imposes little or no constraint on subsequent courts. On the other hand, the reliance approach flattens such distinctions and categories because it suggests that we evaluate all potential sources of precedent with the same set of questions: Did people rely on it? Was the reliance legitimate? And what are the costs of overturning the precedent? The gulf between the doctrinal discourse and the reliance account for precedent may suggest that there is something of a poor fit between the two, or at the very least that accepting the reliance account requires a substantial doctrinal shift.

However, this is not the case. Instead, it may be that the quasiformalist discourse surrounding precedent arises precisely because of the underlying force and potential reach of the reliance approach. Categorization may also offer a way to mitigate the tipping point problem. By introducing ranked categories of precedent, judges offer cues to the public as to what is legitimate to rely upon and, accordingly, what will carry the most force. Categorization sends the following message: Supreme Court precedent is more worthy of public reliance than are lower court opinions, which are more worthy than pronouncements from administrative agencies, which are more worthy than social practices. The public takes these signals into account in deciding how to act. Thus, in shaping public reliance according to this

${ }^{247}$ See supra Part III.C. 
categorical approach, the costs of openly embracing the reliance approach may be mitigated. 248

Finally, it is worth acknowledging that, as with any farreaching legal theory, there are costs and unknowns associated with the reliance approach and that it may produce uncertaineven poor-results in some cases. But these costs are dwarfed by the benefits of the reliance approach, which provides a coherent justification for precedent that is sensitive to the moral implications of the judicial power and that offers both neutral principles and practical tools for deciding whether and when precedent should have normative force.

\section{CONCLUSION: REVISING THE GRAVITATIONAL ACCOUNT OF LAW}

The reliance approach to precedent has potentially vast implications. But perhaps its most important and broadest, if abstract, implication is that it challenges the dominant narrative of law. Legal rhetoric typically assumes and asserts that law is intensely gravitational: it flows from the top (legislatures and higher courts) to the bottom (lower courts, administrative agencies, and the public at large). But the reliance approach upsets this account by insisting that law does-must-flow the other way as well. Precedent takes its power from its affect on the public, and this, in turn, determines whether a court should give normative force to precedent. Likewise, higher courts are and should be constrained by the precedents developed by actors further down the legal hierarchy. Judges and scholars would do well to better articulate this bi-gravitational force and, accordingly, to treat what goes on in lower courts and administrative agencies, and even social norms and behaviors, as potential sources of law.

\footnotetext{
248 Still, there will be cases, as we have seen, in which public reliance interests will develop around even "lesser precedents" to the point at which it might be obligatory for courts to recognize them as having normative force. Judges no doubt disagree about when such a point has been reached. But there will always be difficult cases, whatever approach to the law we have, in which judges, legal scholars, and the broader public will disagree about the proper outcome.
} 